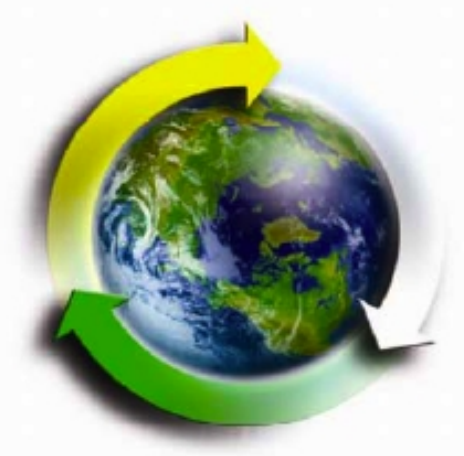

Review of Transmutation Fuel Studies

Global Nuclear Energy Partnership

Prepared for

U.S. Department of Energy Transmutation Fuel Campaign

Jon Carmack Kemal O. Pasamehmetoglu

January 2008 GNEP-FUEL-TD-RT-2008-000050

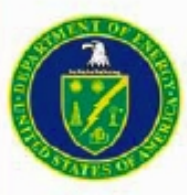




\section{Review of Transmutation Fuel Studies}

Jon Carmack

Kemal O. Pasamehmetoglu

January 2008

\section{Idaho National Laboratory \\ Idaho Falls, Idaho 83415}

Prepared for the

U.S. Department of Energy

Office of Nuclear Energy

Under DOE Idaho Operations Office

Contract DE-AC07-05ID14517 


\section{DISCLAIMER}

This information was prepared as an account of work sponsored by an agency of the U.S. Government. Neither the U.S. Government nor any agency thereof, nor any of their employees, makes any warranty, expressed or implied, or assumes any legal liability or responsibility for the accuracy, completeness, or usefulness, of any information, apparatus, product, or process disclosed, or represents that its use would not infringe privately owned rights. References herein to any specific commercial product, process, or service by trade name, trade mark, manufacturer, or otherwise, does not necessarily constitute or imply its endorsement, recommendation, or favoring by the U.S. Government or any agency thereof. The views and opinions of authors expressed herein do not necessarily state or reflect those of the U.S. Government or any agency thereof. 
Reviewed by:

Director, Transmutation Fuel Campaign

Transmutation Fuel Campaign Director

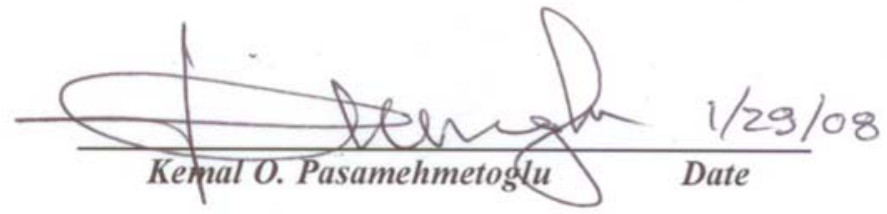

Deputy Director, Transmutation Fuel Campaign

Transmutation Fuel Campaign Deputy Director

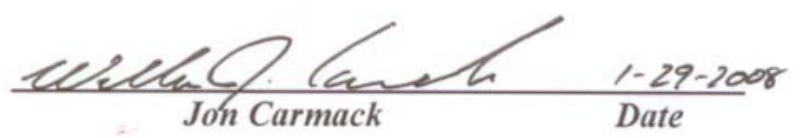


INTENTIONALLY BLANK 


\section{SUMMARY}

The technology demonstration element of the Global Nuclear Energy Partnership (GNEP) program is aimed at demonstrating the closure of the fuel cycle by destroying the transuranic (TRU) elements separated from spent nuclear fuel (SNF). Multiple recycle through fast reactors is used for burning the TRU initially separated from light-water reactor (LWR) spent nuclear fuel. For the initial technology demonstration, the preferred option to demonstrate the closed fuel cycle destruction of TRU materials is a sodium-cooled fast reactor (FR) used as burner reactor. The sodium-cooled fast reactor represents the most mature sodium reactor technology available today. This report provides a review of the current state of development of fuel systems relevant to the sodium-cooled fast reactor. This report also provides a review of research and development of TRU-metal alloy and TRU-oxide composition fuels. Experiments providing data supporting the understanding of minor actinide (MA)-bearing fuel systems are summarized and referenced. 
INTENTIONALLY BLANK 


\section{CONTENTS}

SUMMARY $\mathrm{V}$

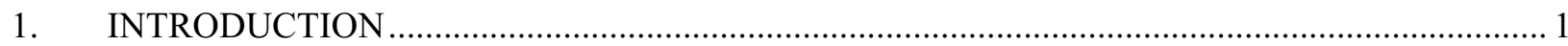

2. FUEL REQUIREMENTS AND SELECTION CONSIDERATIONS .......................................... 3

3. REVIEW OF CONVENTIONAL (U and U-Pu BASED) FAST REACTOR FUEL

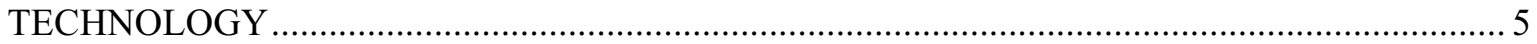

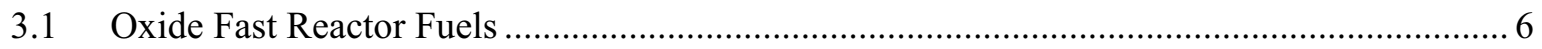

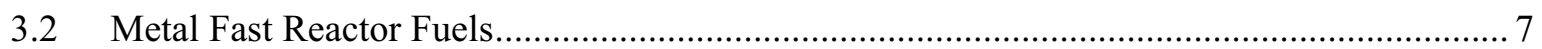

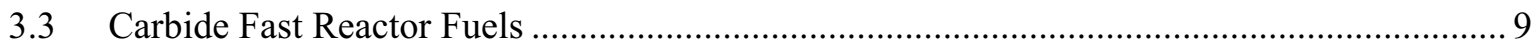

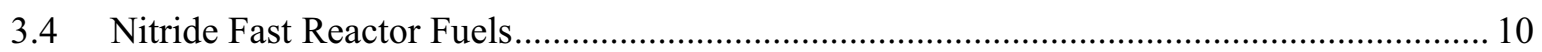

4. REVIEW OF MA-BEARING TRANSMUTATION FUEL TECHNOLOGY .............................. 10

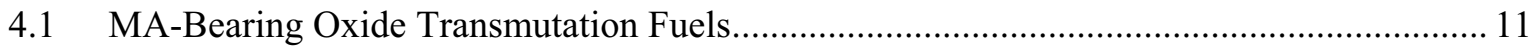

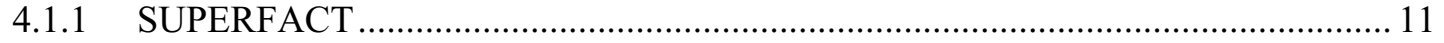

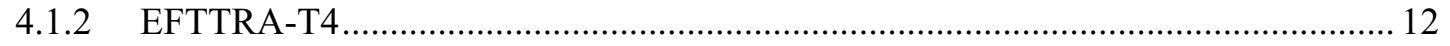

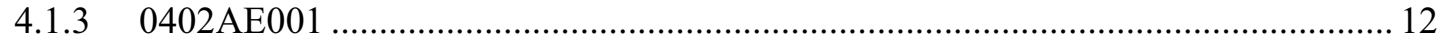

4.1.4 GACID (Global Actinide Cycle International Demonstration) ……......................... 12

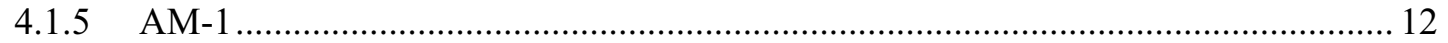

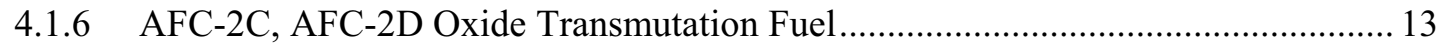

4.1.7 JOYO Irradiation Tests in support of GNEP Oxide Fuel Compositions ................... 14

4.2 MA-Bearing Metal Transmutation Fuels ..................................................................... 14

4.2.1 X501 U-Pu-Zr-Am-Np Metal Fuel Experiment....................................................... 15

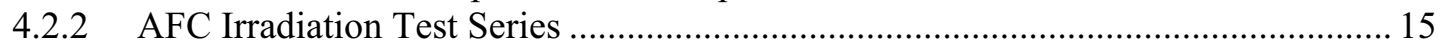

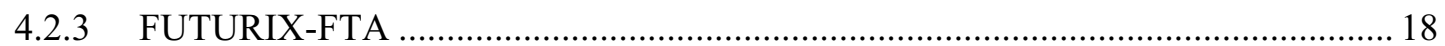

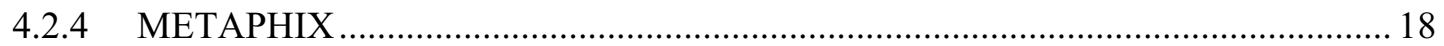

4.2.5 Joyo Irradiation Tests in Support of GNEP Metal Alloy Fuel Compositions............. 19

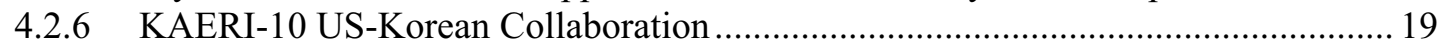

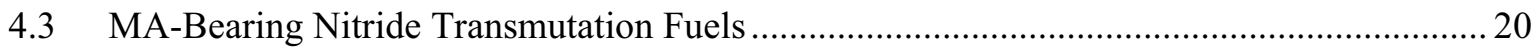

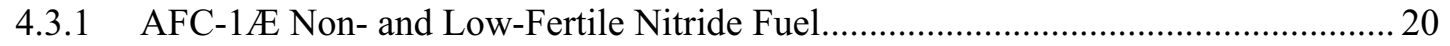

4.3.2 AFC-1G Low-Fertile Nitride and Non-Fertile Metallic Fuel.................................... 21

4.4 MA-Bearing Carbide Transmutation Fuels.................................................................. 21

4.5 MA-Bearing Dispersion Transmutation Fuels ................................................................. 22

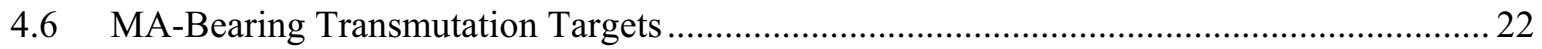

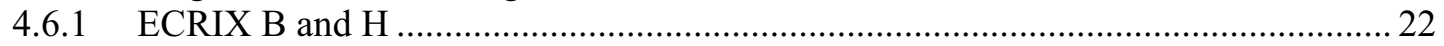

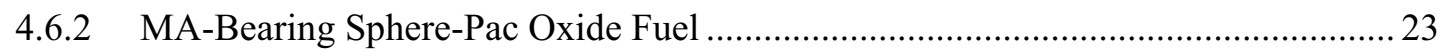

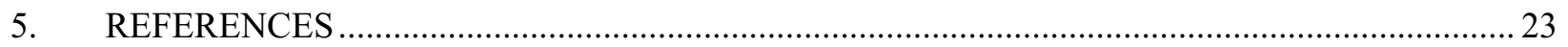

\section{FIGURES}

Figure 1. Photomicrograph of 5\% Am-MOX fuel from the AM-1 10-minute irradiation in Joyo ${ }^{49}$. .13

Figure 2. PIE results of TRU-bearing metallic fuels from the AFC-1B and AFC-1D irradiation experiments. 


\section{TABLES}

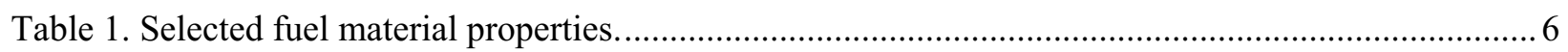

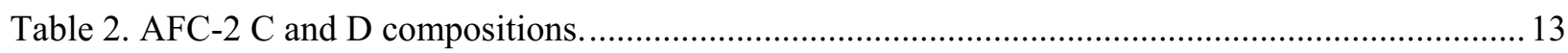

Table 3. Proposed oxide compositions for Joyo. ............................................................................... 14

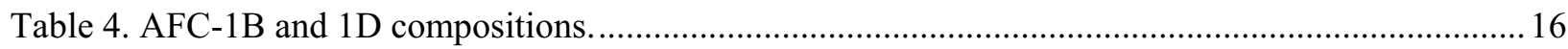

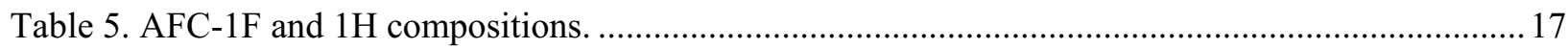

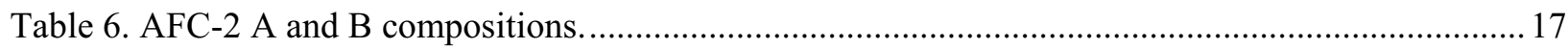

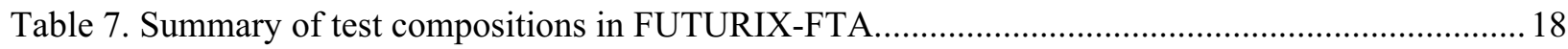

Table 8. Proposed metal alloy compositions for Joyo. .......................................................................... 19

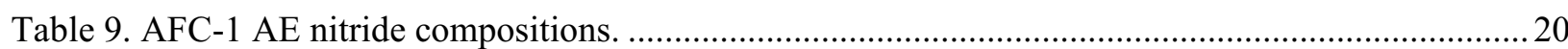

Table 10. AFC-1 G Nitride and non-fertile metal compositions. ............................................................21 


\section{REVIEW OF TRANSMUTATION FUEL STUDIES}

\section{INTRODUCTION}

All transmutation fuel forms considered during this review are currently in an early stage of development. In terms of the technology readiness level, pellet-type oxide and cast metal fuel forms are judged to be at a higher level of maturity relative to other fuel forms considered (e.g., vibro-pac oxides, nitrides, carbides). Considering risk reduction for an early demonstration, it is recommended that oxide and metal fuels be investigated in parallel for an additional 5 to 6 year period prior to a final down-selection for the initial demonstration around 2016. Even with these fuel forms, there is a risk of not meeting the long-term technology demonstration objectives, and backup options are identified and discussed.

The technology demonstration element of the Global Nuclear Energy Partnership (GNEP) program is aimed at demonstrating the closure of the fuel cycle by destroying the transuranic (TRU) elements separated from spent nuclear fuel (SNF). Multiple recycle through fast reactors is used for burning the TRU initially separated from light-water reactor (LWR) spent nuclear fuel. For the initial technology demonstration, it is assumed that a sodium-cooled fast reactor (FR) will be used as a burner reactor, as it represents the most mature fast reactor technology available today.

The initial step in the process is separation of TRU from uranium (U) and fission products (FP) found in LWR SNF. Roughly $90 \%$ of the TRU is plutonium $(\mathrm{Pu})$ with $\sim 10 \%$ being minor actinides (MA) consisting of americium $(\mathrm{Am})$, neptunium $(\mathrm{Np})$, and curium $(\mathrm{Cm})$. The separated TRU is blended with either recycled or depleted $U$ (the use of natural $U$ also is an option) to fabricate FR transmutation fuel. After achieving a specific burnup in the FR, the fuel is recycled. After a TRU fuel assembly achieves the desired burnup in the fast reactor, the TRU is separated from the FR SNF and re-fabricated into fresh FR fuel for subsequent cycles. The TRU destroyed in each cycle is replenished by TRU obtained from LWR SNF.

The transmutation fuel needed for use in a fast reactor differs from conventional thermal and fast reactor fuels in many ways.

A. Instead of a single heavy metal (HM) element (U) or at most two elements $(\mathrm{U}, \mathrm{Pu})$, transmutation fuels are made of a blend of five $\mathrm{HM}$ elements ( $\mathrm{U}, \mathrm{Pu}, \mathrm{Am}, \mathrm{Np}$, and $\mathrm{Cm}$ ).

B. The HM elements used in the fuel have thermodynamic properties considerably different from $\mathrm{U}$ and $\mathrm{Pu}$, and the effect of added minor actinide heavy metals on fuel properties must be factored into the fabrication process. As an example, the high vapor pressure of Am requires that the high temperature fabrication processes typically used in fuel fabrication must be revised.

C. The separation processes that provide the TRU feedstock for fuel fabrication carry over some fraction of rare earth elements. The rare earth lanthanide ( $\mathrm{Ln}$ ) and impurity carryover must be accounted for during TRU fuel fabrication, and the fuel must maintain performance despite the impurities during irradiation in the reactor.

D. High helium generation during irradiation and post-irradiation storage of the Am-bearing fuels must be accommodated by fuel design to limit fuel swelling and excessive pressurization of the fuel pins. 
E. Because of the high radiation doses associated with MA and FP contained in the feedstock, all fabrication, maintenance and quality control operations for transmutation fuel production must be performed remotely in heavily shielded, alpha-capable hot-cells.

F. Finally, the TRU fuel form must accommodate variable composition in terms of the ratio and content of the HM elements and the FP impurities. The variations in composition are due to:

- The burnup of the LWR SNF and the cooling time after discharge from the LWR;

- Burnup level and number of recycles in the FRs; and

- The potential design variations of the FRs to accommodate varying conversion ratios.

It is important to note that the compositional and isotopic variability of interest in the FR fuel is much wider than the technical specifications used in a conventional fuel obtained from a uniform feedstock.

Considering all the differences listed above, it cannot be argued that the transmutation fuels of interest are a simple extension of previously deployed conventional fuels. TRU fuel composition fabrication and performance require further research and development.

Based on the necessity to reduce risk of deployment, it is concluded that pellet-type oxide fuels and cast metal fuels are the primary candidates for an early technology demonstration of fast reactor transmutation. This conclusion is reached based on the following considerations:

- Mature analog fuels (U-Pu based) technologies exist for fabrication, and irradiation performance has been proven on a large scale.

- Limited experimental data to date with MA-bearing fuels (domestic and international) show that TRU fuels are feasible, and the behavior observed to date does not significantly deviate from the corresponding U-Pu based fuel behavior.

- Even though all transmutation fuels forms are in the early stage of development, the technology readiness level for oxide and metal fuels is ahead of other fuel forms based on available fabrication and irradiation data.

- There is understanding of and more extensive databases for both conventional and TRU-bearing oxide and metal fuel properties when compared to other fuel forms.

- Near-term experiments planned in France and Japan for oxide transmutation fuels are expected to provide additional early confirmatory fuel performance data.

- Metal and oxide fuels are completely compatible with the separations technologies being developed under GNEP. Oxide fuels can be processed by aqueous or electrochemical after the initial reduction. Metal fuels are a natural match with electrochemical processing technology.

- Successful laboratory-scale fabrications of metal and oxide fuels have been demonstration with minimal loss of Am.

- Based on the limited data available to date and projections of fuel performance based on scientific judgment, the risk of meeting the initial demonstration objectives are lower for oxide and metal fuels compared to other fuel forms.

Because of these factors, the risk of achieving a successful first demonstration with one of these fuel forms is lower than the alternatives. Because unexpected issues may arise during fuel development, it is recommended that both fuel forms be further studied until adequate data are available for a more informed selection. Pending the availability of the necessary resources, down-selection is scheduled for 2014 for the initial demonstration. 
The remaining major issues for oxide fuel development are (a) the economics of pellet fabrication in a fully remote environment, (b) oxygen stoichiometry control with group TRU feedstock (especially in the presence of FP contamination in the feedstock), (c) product reliability with moderate sintering temperatures, and (d) achievable burnup without fuel failure due to unknown species mobility and swelling behavior at high americium loading.

For metal fuel, the major issues are (a) large-scale remote fabrication without loss of Am (rapid melting and casting), (b) fuel-clad interactions at moderate to high burnups especially in the presence of lanthanide contamination in the feedstock, and (c) pyroprocessing that meets TRU recovery and Ln decontamination requirements.

In addition, other backup options also are considered to minimize the risk for achieving the long-term demonstration goals.

For oxide fuel forms, vibro-pac (or sphere-pac) fabrication is considered. This is a longer-term option because it requires additional irradiation performance testing. For metal fuel, developmental low temperature, rapid fabrication processes may provide an alternative to rapid melting and casting. In case a engineering scale fabrication route having acceptably low Am losses cannot be developed, Am recovery and subsequent Am target development can be considered as a backup technology option.

Research-scale development for nitride and dispersion fuels also is planned. The near-term emphasis will be on addressing major feasibility issues for potential demonstration as second or third generation transmutation fuels. Nitride fuels have advantages in terms of high HM loading and high thermal conductivity. Dispersion fuels may be advantageous, allowing very high burnups. If additional investigation of carbide fuels is to be pursued, a feasible separations technology must first be developed and demonstrated.

\section{FUEL REQUIREMENTS AND SELECTION CONSIDERATIONS}

Based on the technology demonstration objectives summarized above, the following are the primary performance requirements for the transmutation fuels.

1. The fuel must accommodate $\mathrm{Pu}$ and MA delivered as a group in the feedstock supplied by the separations process within a wide composition range. Group separation of the TRU is targeted for the initial demonstration because of (a) non-proliferation considerations, and (b) the desire to achieve a closed fuel cycle with a single new fuel form.

2. The fuel must be able to achieve as high a burnup as possible (potentially up to $250 \mathrm{GWd} /$ ton $\mathrm{HM}$ ). Higher burnup than conventional FR fuels is necessary to minimize (a) the losses that naturally occur each time FR fuel is recycled, and (b) fuel cycle cost that is expected to increase with increasing number of recycles for equivalent energy production.

3. The fabrication and quality control process must be amenable to fully remotized operations in hot cells, including equipment maintenance.

4. The unrecoverable TRU losses during fabrication must be minimized with a long-term target of $<<1 \%$ prior to commercialization.

5. The fuel form must be compatible with sodium coolant to prevent undesirable consequences resulting from a clad breach event.

6. To prevent extensive development of new clad alloys for the initial demonstration, the fuel form must be compatible with known clad materials or with clad materials that require modest modifications. 
7. The fuel form must be compatible with the reprocessing scheme selected for recycling fast reactor fuel. The recycling scheme and fuel form selections must be done simultaneously to ensure that the technologies are compatible for optimal fuel cycle performance.

8. Based on the currently anticipated GNEP deployment schedule, fuel development must be completed through lead-test assembly qualification within 20 years. Therefore, fuel forms with the highest technology readiness level and minimum technical risk will be selected as candidates for the initial technology demonstration.

To assess the overall technology readiness level, both fuel fabrication and fuel performance must be considered. ${ }^{1}$ For fuel fabrication, the scale of fabrication development performed to date must be evaluated considering that demonstration-scale fabrication must be completed using fully remote operations in shielded hot cells. The technology risk must therefore be evaluated based on available experience in fabricating fuel using hot cell operations.

For fuel performance, the technology readiness level assessment is based on the accumulated fuel performance database, including the number and the prototypicality of the irradiation experiments. Likewise, the technology risk must be assessed comparing the expected behavior of TRU fuels to the behavior of similar conventional fuel forms using a more fundamental understanding of such fuels. This assessment requires knowledge of the fuel properties (thermal, mechanical, and chemical) and their anticipated changes during irradiation using analog fuel systems. TRU fuel technology readiness assessment must also include the anticipated transient (safety) behavior of the TRU fuel forms based on extrapolation from conventional fuel transient behavior.

Conventional U or U-Pu based fuels are well-demonstrated technologies currently in use at large scale in fast reactors around the world. As discussed above, transmutation fuel is considerably different than conventional U or U-Pu fuels. Therefore, it is unwise to base the fuel selection solely on the technology maturity of the conventional fuel forms. However, to the extent that additional development can demonstrate that transmutation fuel behavior during fabrication and irradiation does not deviate significantly from conventional fuel behavior, the qualification program can be considerably simplified. Consequently, in selection of the transmutation fuel form, the technology maturity of the analog fuel forms that contain only $\mathrm{Pu}$ (as opposed to full TRU with $\sim 0.9 \% \mathrm{Pu}$ ) must be considered.

Finally, the technology readiness level and technological risk associated with the reprocessing technology for a given fuel form must be considered in assessing the overall fuel development requirements. 


\section{REVIEW OF CONVENTIONAL (U and U-PU BASED) FAST REACTOR FUEL TECHNOLOGY}

A brief review of the conventional fast reactor fuel technology is provided in this section. A more extensive review of conventional fast reactor fuel technology is provided in Crawford et al. ${ }^{1}$ Conventional fuel is defined as fuel forms that use high enriched uranium (HEU) or U-Pu, that have been developed in domestic and international FR programs. The review presented here is not meant to be exhaustive. Features believed to be pertinent to transmutation fuel technology are summarized with the reader referred to the appropriate literature reference for further detail.

The goal of the GNEP transmutation fuel development program is to develop and qualify a nuclear fuel system that performs all of the functions of a traditional fast spectrum nuclear fuel while destroying recycled actinides. This fuel would provide a mechanism for closure of the nuclear fuel cycle, providing for implementation of the GNEP program. Oxide and metal fuels are currently the two primary candidates under consideration for this application, based on historical knowledge of fast reactor fuel development and specific fuel tests currently being conducted in the United States and international transmutation fuel development programs. Fast reactor development programs have been conducted in the United States and internationally over the past five decades. Early fast reactor developers originally favored metal alloy fuel due to its high density and potential for breeder operation. The focus of naval reactor pressurized water reactor development on oxide fuel and the subsequent adoption by the commercial nuclear power industry, however, along with early issues with low burnup potential of metal fuel (now resolved), led later fast reactor development programs to favor oxide fuels. Carbide and nitride fuels have also been investigated but are at a much lower state of development than metal and oxide fuels, with limited large-scale reactor irradiation experience.

Experience with both metal and oxide fuels has established that either fuel type will meet performance and reliability goals for a plutonium fueled fast-spectrum test reactor, ${ }^{3}$ both demonstrating burnup capability of up to 20 at.\% under normal operating conditions, ${ }^{4,5,6,7}$ when clad with modified-austenitic or ferritic-martensitic stainless steel alloys. Both metal and oxide fuels have been shown to exhibit sufficient margin to failure under transient conditions for successful reactor operation. ${ }^{8,9,10,11,12}$ Post-breach operation of metal fuel in a sodium-cooled system is benign, while consequences for post-breach operation of mixed oxide is somewhat design dependent but still feasible. $^{13,14}$

Table 1 provides a summary of selected fuel material properties taken from Smith et al. ${ }^{15}$ As noted above, decisions on fuel selection for a closed-cycle system are complex and have implications beyond fuel fabrication and performance. For example, there are obvious differences between the melting points and the thermal conductivities of metal and oxide fuels. The thermal conductivity of metal fuel is clearly superior to oxide fuel, yielding a lower centerline operating temperature. On the other hand, metal fuel has a much lower fuel melting point than oxide fuel. The accident behavior of the fuels, however, is the parameter of importance, and differences in behavior cannot be catalogued by any method other than experimental testing. 
Table 1. Selected fuel material properties.

\begin{tabular}{|c|c|c|c|c|}
\hline $\begin{array}{c}\text { Fast Reactor Fuel Type Fresh } \\
\text { Fuel Properties }\end{array}$ & $\begin{array}{c}\text { Metal } \\
(\mathrm{U}-20 \mathrm{Pu}-10 \mathrm{Zr}) \\
\end{array}$ & $\begin{array}{c}\text { Oxide } \\
\left(\mathrm{UO}_{2}-20 \mathrm{PuO}_{2}\right) \\
\end{array}$ & $\begin{array}{c}\text { Nitride } \\
(\mathrm{UN}-20 \mathrm{PuN})\end{array}$ & $\begin{array}{c}\text { Carbide } \\
(\mathrm{UC}-20 \mathrm{PuC})\end{array}$ \\
\hline Heavy Metal Density $\left(\mathrm{g} / \mathrm{cm}^{3}\right)$ & 14.1 & 9.3 & 13.1 & 12.4 \\
\hline Melting Point, $\mathrm{K}$ & 1350 & 3000 & 3035 & 2575 \\
\hline Thermal Conductivity, W/m-K & 16 & 2.3 & 26 & 20 \\
\hline $\begin{array}{l}\text { Operating Centerline } \\
\text { Temperature at } 40 \mathrm{~kW} / \mathrm{m} \text {, } \\
\left(\mathrm{T} / \mathrm{T}_{\text {melt }}\right)\end{array}$ & $\begin{array}{l}1060 \\
(0.8)\end{array}$ & $\begin{array}{l}2360 \\
(0.8)\end{array}$ & $\begin{array}{l}1000 \\
(0.3)\end{array}$ & $\begin{array}{l}1030 \\
(0.4)\end{array}$ \\
\hline Fuel-Cladding Solidus, K & 935 & 1675 & 1400 & 1390 \\
\hline Thermal Expansion, 1/K & $17 \mathrm{E}-6$ & $12 \mathrm{E}-6$ & $10 \mathrm{E}-6$ & $12 \mathrm{E}-6$ \\
\hline Heat Capacity, J/g-K & 17 & 34 & 26 & 26 \\
\hline Reactor Experience, Country & US, UK & $\begin{array}{l}\text { RUS, FR, JPA, } \\
\text { US, UK }\end{array}$ & RUS & IND \\
\hline Research and Testing, Country & $\begin{array}{l}\text { US, JAP, } \\
\text { ROK, CHI }\end{array}$ & $\begin{array}{c}\text { RUS, FR, JAP, } \\
\text { CHI }\end{array}$ & US, RUS, JAP & IND \\
\hline
\end{tabular}

\subsection{Oxide Fast Reactor Fuels}

Oxide-based fuel has been the choice of most reactor development and demonstration programs over the history of domestic and international fast reactor development. Two performance issues exist for the oxide fuel system. First, the oxide fuel system has a low thermal conductivity leading to high fuel centerline operating temperatures. Thermal conductivity is further reduced by the addition of the minor actinides and fission products during operation. Tight fuel pellet dimensional tolerances must be maintained during fabrication to ensure that the fuel pellet swells just enough to contact the fuel cladding but not to the point that undue strain is placed on the cladding as the fuel swells into contact with the cladding. Slight contact with the cladding provides the heat transfer conduction path needed to efficiently transfer heat from the fuel through the cladding to the reactor coolant. Oxide fuels are also reactive with liquid metals. This issue must be taken into account when considering consequences of a fuel cladding breach and resulting ingress of liquid metal coolant in contact with bare oxide fuel.

FFTF oxide fuel development, demonstration, and testing provided the most extensive generation of performance data on fast spectrum mixed-oxide fuel systems in the United States. Oxide performance as tabulated by Leggett and Walters ${ }^{3}$ is as follows:

- $\quad>48,000$ mixed (U, Pu) oxide (MOX) pins achieved 8\% burnup in 316SS (Series I\&II) as FFTF driver fuel

- 500 pins achieved $>220 \mathrm{MWd} / \mathrm{kgM}$ burnup in cold-worked stainless steel

- CW SS has demonstrated acceptable performance to between 80 and $100 \mathrm{MWd} / \mathrm{kgM}$ with only 1 pin breach at $103 \mathrm{MWd} / \mathrm{kgM}$

- Irradiation induced swelling is the life-limiting factor in $316 \mathrm{SS}$ with $20 \% \mathrm{CW}$ 
- Fuel assemblies have accumulated $12 \times 10^{22} \mathrm{n} / \mathrm{cm}^{2}$ flux and 8 to 10 at $\%$ burnup

- Extended lifetime has been demonstrated in D9 cladding to $188 \mathrm{MWd} / \mathrm{kgM}$ (fast fluence at $27 \times 10^{22}$ $\mathrm{n} / \mathrm{cm}^{2}$ conservative $18 \times 10^{22} \mathrm{n} / \mathrm{cm}^{2}$

- Ferritic-Martensitic steels (i.e. HT9) would provide extended lifetimes upwards of $220 \mathrm{MWd} / \mathrm{kgM}$

- Fuel pins have operated with peak clad temperatures of $660^{\circ} \mathrm{C}$.

Recycling technology for light water reactor oxide fuel has been established on an industrial scale. Remote fabrication of pellet-type oxide fuel has not been demonstrated; however, fabrication capacity for more than 200 tons of MOX fuel exists worldwide. The LWR MOX fuel is fabricated in a "semi-remote" environment, where equipment operation has been automated with maintenance and decontamination activities performed hands-on.

\subsection{Metal Fast Reactor Fuels}

Metal fuel was selected for fueling many of the first reactors in the U.S., including the plutonium production reactors operated at Hanford, the Experimental Breeder Reactor (EBR)-I and EBR-II in Idaho, the Fermi-I power reactor in Michigan, and the Dounreay Fast Reactor (DFR) in the U.K. ${ }^{16,17}$ Metallic U-Pu-Zr alloys were the reference fuel for the U.S. Integral Fast Reactor (IFR) program. ${ }^{18,19}$ Metallic $\mathrm{U}-\mathrm{Pu}-\mathrm{Zr}$ alloys were the reference fuel for the U.S. IFR program, and an extensive database on the performance of advanced metal fuels was generated from this program. These data include the remote fabrication and irradiation in EBR-II of approximately 35,000 Mark-I driver fuel rods from 1964 to $1969,{ }^{20}$ over 30,000 Mark-II driver fuel rods, ${ }^{21,22}$ 13,000 Mark-III/IIIA/IV (U-10Zr alloy) driver fuel rods, and over $600 \mathrm{U}-\mathrm{Pu}-\mathrm{Zr}$ fuel rods. ${ }^{21,22}$ Mark-II driver fuel was qualified for 8 at.\% burnup, while Mark-IIIA driver fuel was qualified for 10 at.\% burnup. U-Pu-Zr and U-Zr rods clad in Type 316, D9 or HT9 cladding reached terminal burnup values of 15 to $>19$ at.\% burnup without breach. ${ }^{23,25}$ Some 2 -sigma high-temperature assemblies reached 11 to 12 at.\% burnup without breach. ${ }^{26}$ In addition to EBR-II irradiations, over $1050 \mathrm{U}-10 \mathrm{Zr}$ fuel rods and $37 \mathrm{U}-\mathrm{Pu}-\mathrm{Zr}$ fuel rods were irradiated in the FFTF to burnup values above 14 at. $\%$ and 9 at. $\%$, respectively. ${ }^{27}$ The significance of these irradiation tests were to 1) effectively qualify U-Zr metal fuel as the Series III.b driver fuel for Fast Flux Test Facility (FFTF), and 2) demonstrate that there were no length effects in metal fuel that were obscured by the relatively short core height of EBR-II. ${ }^{26}$

Metal fuel alloys have a propensity toward high gas-driven swelling. Initially, early metal alloy fuel designs attempted to restrain swelling. This resulted in unacceptably large cladding deformation at low burnup. Later designs allowed for fuel swelling by increasing the fuel-clad gap size. This configuration allows the fuel to freely swell about $30 \%$ by volume before contacting the cladding wall. At this point, the fuel develops a network of interconnected porosity, resulting in a weak mass that cannot exert substantial mechanical force on the cladding. The network of porosity leads to a high gas release rate, on the order of $80 \%$. Since metal fuel is engineered to allow for swelling and promote gas release, the issue of helium generation due to americium and curium is a matter of (1) sizing the gas plenum to prevent excessive gas pressure driven cladding creep, and (2) ensuring that gap size is adequate to accommodate solid fission product swelling. 
Safety testing established the acceptable behavior of metal fuel during accident conditions. Assessment of safety of an operating fast reactor requires an understanding of how fuel rods and bundles behave under off-normal conditions. The six M-series tests performed in the Transient Reactor Test Facility (TREAT) evaluated transient-overpower margin to failure, pre-failure axial fuel expansion, and post-failure fuel and coolant behavior for 15 rods with various combinations of U-5Fs, ${ }^{a} \mathrm{U}-\mathrm{Zr}$, and U-Pu-Zr fuel clad in Type 316, D9, and HT9 stainless steel. ${ }^{28,29}$ The results consistently showed that metal fuel rods of modern design exhibited failure thresholds around 4 times nominal power (under the relatively fast transient-overpower conditions used in the tests). Fuel rod breaches that occurred were located at the top of the fuel column and, in all cases, were attributed to cladding rupture induced by pin-plenum pressurization and cladding thinning due to eutectic-like formation of a molten fuel/cladding phase that penetrated the cladding wall. Pre-failure axial fuel expansion (that has the beneficial effect of removing reactivity from the core during an overpower transient) for the U-Pu-Zr and U-Zr was similar to that observed with higher-burnup U-5Fs fuel, and in amounts significantly greater than would be caused by thermal expansion alone. Post-failure behavior observed in all tests was characterized by rapid fuel dispersal, with about half of the fuel inventory being ejected from the fuel rod - again, with the beneficial effect of removing reactivity from the core during postulated severe accidents. The data from these tests and from a large number of prior metal fuel transient tests in TREAT were used to develop and validate models of fuel behavior under transient overpower conditions. ${ }^{30,31}$ Other safety-related testing focused on fuel behavior during unlikely loss-of-flow events using hot-cell furnace heating tests of irradiated U-Pu-Zr clad in HT9. ${ }^{32,33}$ The results demonstrated significant safety margin for the particular transient conditions studied (a bounding unlikely loss-of-flow event for EBR-II). The observed cladding breaches were induced by pin-plenum gas pressure at temperature, with cladding thinning due to eutectic-like formation of a molten fuel/cladding phase. In addition, fission gas expansion in the fuel induced axial fuel expansion, enabled by reduction of constraint from the cladding with formation of the molten phase at the fuel/cladding interface. The data from these tests, and other similar tests, were used to develop and validate models of metal fuel behavior under loss-of-flow conditions. ${ }^{33,31}$

a Fs is designated as the symbol for fissium, a simulated mixture of noble-metal fission products produced in equilibrium with the original EBR-II melt-refining pyrometallurgical recycle process. Fs: $2.4 \mathrm{wt} \% \mathrm{Mo}, 1.9 \mathrm{wt} \% \mathrm{Ru}, 0.3 \mathrm{wt} \% \mathrm{Rh}, 0.2 \mathrm{wt} \% \mathrm{Pd}$, $0.1 \mathrm{wt} \% \mathrm{Zr}, 0.01 \mathrm{wt} . \% \mathrm{Nb}$ 


\subsection{Carbide Fast Reactor Fuels}

Although much smaller than that for either metal or oxide fuels, the irradiation performance database for $(\mathrm{U}, \mathrm{Pu}) \mathrm{C}$ mixed carbide $(\mathrm{MC})$ fuels is not inconsequential. ${ }^{34,35}$ Over $470 \mathrm{MC}$ fuel rods were irradiated in EBR-II using a range of parameters, sodium or helium bonding, and cladding made from Type 316 stainless steel, PE-16 (a nickel-based alloy used in the U.K.), D9 stainless steel, or D21 stainless steel. ${ }^{35}$ A peak fuel burnup in $10 \mathrm{MC}$ fuel rods clad in Type 316 stainless steel of 20 at.\% was achieved in EBR-II. ${ }^{42,36}$ Of those rods, 5 had experienced a $15 \%$ transient-overpower test in EBR-II after attaining 12 at.\% burnup. Twenty one cladding breaches occurred in the EBR-II tests prior to reaching goal burnup. Fifteen were in PE-16-clad rods at locations under the wire wrap and attributed to irradiation embrittlement in the PE-16 cladding alloy rendering it less capable of enduring the stress induced by fuel cladding mechanical interaction (FCMI) and fission gas pressure. The remaining 6 were observed to be in Na-bonded rods, but those results were deemed less relevant because emphasis was placed on He-bonded MC fuel as the reference. ${ }^{35}$ Over $200 \mathrm{MC}$ fuel rods were irradiated in FFTF in two assemblies: the ACN-1 experiments with rods fabricated using Type 316SS and D9 cladding, and the FC-1 test, which was a full-size, 91-rod FFTF assembly using Type 316SS and D9 cladding and ducts. ${ }^{34,35,37,38}$ One rod breached in FFTF, but there was no post-irradiation examination of that rod. The AC-3 test was composed of 91 full-size, D9-clad rods of which 25 rods contained sphere-pac fuel and 66 rods contained pellet fuel. ${ }^{37,38,48}$ That assembly was irradiated to the goal 9 at.\% burnup without breach. For the relatively low-temperature conditions used for the test, the pellet fuel and sphere-pac exhibited only minor observed differences in behavior, and both performed in a manner consistent with the bulk of the MC fuel database. ${ }^{38}$

Carbide fuel failures typically result from fuel cladding mechanical interaction FCMI, owing to the fact that fuel swelling is greater than that of the oxide which leads to early fuel/cladding gap closure, and since cladding generally operates at relatively low temperature creep is not effective at relieving cladding stress. ${ }^{37}$ For this reason, MC fuel pin design must incorporate a large fuel/cladding gap and make use of a low-density fuel in order to delay the onset of FCMI. While cladding carburization has been a historical concern for MC fuels, and was observed in the Type 316SS-clad rods irradiated in EBR-II, no fuel failures have been attributed to this specific phenomenon. ${ }^{39,35}$

Transient-overpower tests involving MC fuels were conducted in TREAT using fuel irradiated in EBR-II to burnups ranging from 0 to 12 at.\%, primarily for the purposes of establishing that cladding breach would occur at a margin above that of the FFTF plant protection system settings (at $115 \%$ and $125 \%$ overpower). The results suggested FCMI-induced breaches, but indicated comfortable margins to failure (roughly 3 times nominal linear heat generation rate in a MC fuel and up to 6 times the nominal linear heat generation rate typical of oxide fuel cores). The conclusion of the test series was a determination that nothing in fuel transient-overpower response would prevent or limit application of MC fuels to fast reactors. 39,40 


\subsection{Nitride Fast Reactor Fuels}

The irradiation performance database for $(\mathrm{U}, \mathrm{Pu}) \mathrm{N}$ mixed nitride $(\mathrm{MN})$ fuels is substantially smaller than that for metal carbide (MC) fuels, and these fuels can be considered to be at an early stage of development relative to oxide and metal fuels. Compared to MC fuels, MN fuels exhibit less fuel swelling, lower fission gas release, and are considerably easier to reprocess; however, the problem of the production of biologically hazardous ${ }^{14} \mathrm{C}$ in nitride fuels fabricated using natural nitrogen poses a considerable concern for the reprocessing of $\mathrm{MN}$ fuels. ${ }^{41}$ Interest remains in nitride fuels due to the combination of high thermal conductivity and high melting point. ${ }^{42,43}$

More so than $\mathrm{MC}$ fuels, $\mathrm{MN}$ fuels were found to exhibit extensive cracking and fragmentation during simple startup and shutdown transients if operated at high temperatures. This cracking phenomenon was considered to be the reason for the early fuel failures seen in U.S. irradiation tests. ${ }^{44}$ Use of a metallic shroud around the fuel column to prevent fuel relocation subsequent to fragmentation provided an engineering solution to this problem to some extent. Nevertheless, the U.S. specifications for MN fuels recommended that their peak fuel temperatures be restricted to as low as $1200^{\circ} \mathrm{C}$ to mitigate fragmentation and eliminate the need for the use of shrouds. ${ }^{43,44}$ A further issue of concern regarding $\mathrm{MN}$ fuels was that they dissociate at temperatures substantially lower then their congruent melting point if a nitrogen overpressure is not maintained.

\section{REVIEW OF MA-BEARING TRANSMUTATION FUEL TECHNOLOGY}

Compared to a conventional HEU or U-Pu based FR fuels, MA-bearing transmutation fuels are at an early stage of development. Knowledge is limited to laboratory-scale fabrication, a small amount of characterization and out-of-pile testing, and a small number of irradiation tests. A summary of the existing knowledge along with an assessment of additional development needs for various fuel forms is provided below for each fuel type.

The incorporation of the minor actinides ( $\mathrm{Am}, \mathrm{Np}$, and $\mathrm{Cm}$ ) into a fuel system matrix presents specific challenges related to fuel fabrication as well as irradiation performance. A number of international programs including the U.S. Department of Energy (DOE) have pursued development of TRU bearing fuel compositions. Most of the work in the U.S. has been conducted under the Advanced Fuel Cycle Initiative (AFCI) and its predecessor programs. A variety of TRU bearing oxide, metal, and nitride fuel compositions have been fabricated, irradiated, characterized, and examined following irradiation. Generally, metal fuel compositions containing significant quantities of the minor actinides have only been demonstrated to a low burnup of 2 to 3 at. $\%$ with a fission density equivalent to 20-30 $\mathrm{MWd} / \mathrm{kgM}$.

Transuranic bearing fuel compositions have a limited irradiation experience. Two TRU-oxide tests have been published, EFTTRA-T4 ${ }^{45}$ and SUPERFACT- $1 .{ }^{46,47}$ In addition, one metal fuel test experiment, the X501 test, ${ }^{50}$ was conducted near the end of the EBR-II program. The METAFIX test, conducted by CRIEPI in CEA's Phénix reactor and the AM-1 test conducted by JAEA in Joyo are currently in progress. Other tests include the AFCI LWR-1a test in the Advanced Test Reactor (MOX with 4000 ppm neptunium to 8 at.\% burnup) and the AFC series of TRU metal and nitride fuel tests in the Advanced Test Reactor. 


\subsection{MA-Bearing Oxide Transmutation Fuels}

Considering the demonstrated excellent performance of conventional U-Pu oxide fuels discussed above, oxide fuel provides the base structural matrix for performance as a TRU fuel depending on resolution of the following issues:

- Feasibility and economics of powder processing and pellet fabrication during fully remote operations must be demonstrated.

- Due to Am metal volatility, fabrication with high Am retention must be demonstrated.

- Oxygen to metal stoichiometry control during fabrication and irradiation must be demonstrated, especially with fission product contamination in the feedstock.

- Oxide fuel properties must not be seriously degraded from the $(\mathrm{U}, \mathrm{Pu}) \mathrm{O}_{2}$ system performance by the addition of transuranics.

- Demonstration of an acceptable level of swelling and fuel cladding mechanical interaction with fuel that includes significant levels of americium and curium over the lifetime of the fuel up to its burnup limit, $\sim 20$ at.\%.

- Behavior of TRU oxide fuel under run-beyond-design conditions, over-power transients, and runbeyond-clad breach must be determined.

In early parts of the U.S. transmutation fuel development program, it was decided to focus the U.S. efforts on metal and nitride fuels. It was always recognized that oxide fuel was a strong candidate for transmutation. Considering the emphasis on oxide fuels in France and Japan, a decision was made to focus the limited resources on the other fuel forms while relying on international collaboration activities to monitor the progress on oxide transmutation fuel development. This strategy has been modified such that oxide fuel development is specifically being pursued by the U.S. This is being accomplished by a combination of participation in international oxide development and irradiation programs and by irradiation of U.S. fabricated oxide fuel compositions irradiated in domestic reactors. The U.S.-DOE TRU fuel development program is specifically participating in the GEN-IV Sodium Fast Reactor GACID program and oxide tests in the Joyo fast spectrum test reactor.

Three primary international transuranic oxide fuel tests have been conducted, SUPERFACT, EFTTRA-T4, and 0402AE001. The issues relevant to TRU oxide fuel fabrication and irradiation performance known from these experiments are presented below.

\subsubsection{SUPERFACT}

The SUPERFACT experiment was carried out in the Phénix reactor for 383 EFPDs from 1986-1988 and provides the only relevant data on the behavior of mixed oxide fuel in a homogenous fuel matrix with significant americium and neptunium additions. SUPERFACT contained four pins with high TRU compositions containing up to $45 \% \mathrm{wt} . \%$ neptunium and $20 \mathrm{wt} . \%$ americium that were irradiated to a peak burnup of 4.5 at.\%. The experiment also contained two fuel pins each of compositions $(\mathrm{U}-24 \mathrm{Pu}-1.8 \mathrm{Am}) \mathrm{O}_{\mathrm{x}}$ and $(\mathrm{U}-24 \mathrm{Pu}-1.5 \mathrm{~Np}) \mathrm{O}_{\mathrm{x}}$ that are representative of those envisioned for GNEP fuels. The experiments where conducted at prototypic Linear Heat Generation Rates (LHGR). Three of the four fuel compositions tested in SUPERFACT performed well with only one pin with a very high concentration of Am, (20 wt.\%), exhibiting the onset of fuel clad mechanical interaction and some clad constituent migration into the fuel region. All of the test compositions exhibited high fission gas release as expected in fast reactor oxide fuel due to high fuel centerline temperatures and high mobility of helium gas. The results of the SUPERFACT experiment indicate that a TRU oxide fuel composition would likely exhibit acceptable performance as a fast reactor transmutation fuel. 


\subsubsection{EFTTRA-T4}

The thermal spectrum EFTTRA-T4 test ${ }^{48}$ consisted of a micro dispersion of americium oxide in a magnesium-aluminate spinel matrix. The T4 experiment was irradiated in the HFR-Petten reactor (The Netherlands) during the 1996-1998 time frame. Post-irradiation examination indicated the gas release was a fraction of that measured in the SUPERFACT pins. Pellets in this test exhibited volumetric swelling of $\sim 18$ vol.\%, resulting in excessive cladding strain. This experiment indicates that if americium content is high and if gas is to be retained by the fuel, the matrix material must be carefully chosen to avoid excessive gas-driven swelling. The temperature dependence of swelling and gas release must also be taken into account, so that core thermal excursions do not result in rapid fuel swelling or rapid release of gas resulting in a catastrophic fuel failure.

\subsubsection{AE001}

The 0402AE001 experiment was a collaboration between the UKAEA and the U.S. DOE conducted in the 1984 timeframe. It is largely an unpublished experiment with little data appearing in the open literature. The basis for the test was an Am-Cm-Ln composition in oxide form and, although it does not represent a TRU oxide fuel envisioned for the GNEP TRU oxide fuel form, it is similar to the EFTTRA experiment in that it provides important data on the behavior of americium and curium under irradiation conditions. It also provides one of the few measures of the lanthanide series under irradiation in a refabricated fuel form. The fuel composition was irradiated in a pellet form encapsulated in a D9 cladding. It achieved 1.5 at.\% burnup of the actinides at a centerline temperature $<800^{\circ} \mathrm{C}$ and LHGR between 95 and $105 \mathrm{~W} / \mathrm{cm}$. Little to no fuel constituent migration and no fuel-clad interaction was observed. Helium generation with nearly $100 \%$ release to the plenum was observed. The 0402 AE001 experiment provides a limited measure of the behavior of americium and curium in the presence of the lanthanide series.

\subsubsection{GACID (Global Actinide Cycle International Demonstration)}

The GACID program is an international collaboration between the French CEA, U.S.DOE, and Japan JAEA. It is conducted under the framework of the GEN-IV Sodium Fast Reactor Program. The intent of the program is to demonstrate the burning of the minor actinides $\mathrm{Am}, \mathrm{Np}, \mathrm{Cm}$ in a $20 \% \mathrm{Pu}$ MOX fuel. The $(\mathrm{U}, \mathrm{Pu}, \mathrm{Am}, \mathrm{Np}, \mathrm{Cm}) \mathrm{O}_{\mathrm{x}}$ demonstration is to be conducted in the Monju fast-spectrum power reactor located in Tsuruga, Japan. The demonstration fuel pins will be manufactured in the Atalante hot cells in Marcoule, France using Am, Np, and Cm feedstocks supplied by the United States. The GACID program will also provide for an initial licensing irradiation in the Joyo fast test reactor located in Oarai, Japan fabricated similar to the full scale Monju pin. A significant characterization campaign will also be carried out to support the licensing of both the Joyo and Monju irradiations. The GACID program will provide key irradiation performance data on oxide transmutation fuel. The data obtained from this test will provide feasibility assessment of the MOX fuel matrix for transmutation.

\subsubsection{AM-1}

The AM-1 irradiation test series is being conducted by the JAEA in the JOYO reactor. It consists of the irradiation of standard $20 \%$ Pu-MOX containing multiple pins with varying minor actinide contents of $(3 \% \mathrm{Am}),(5 \% \mathrm{Am})$, and $(2 \% \mathrm{~Np}-2 \% \mathrm{Am})$. The test consists of a 10-minute, high linear power irradiation followed by a 24-hour high linear power irradiation, followed by a steady state irradiation to approximately 10 at.\% burnup. The first two irradiations (10 minute and 24 hour) have been completed and the steady-state irradiation is currently being conducted. Figure 1 shows a photomicrograph indicating normal MOX fuel restructuring behavior. Further results from the AM-1 test series will provide an understanding of americium and neptunium behavior in oxide fuel matrices. 


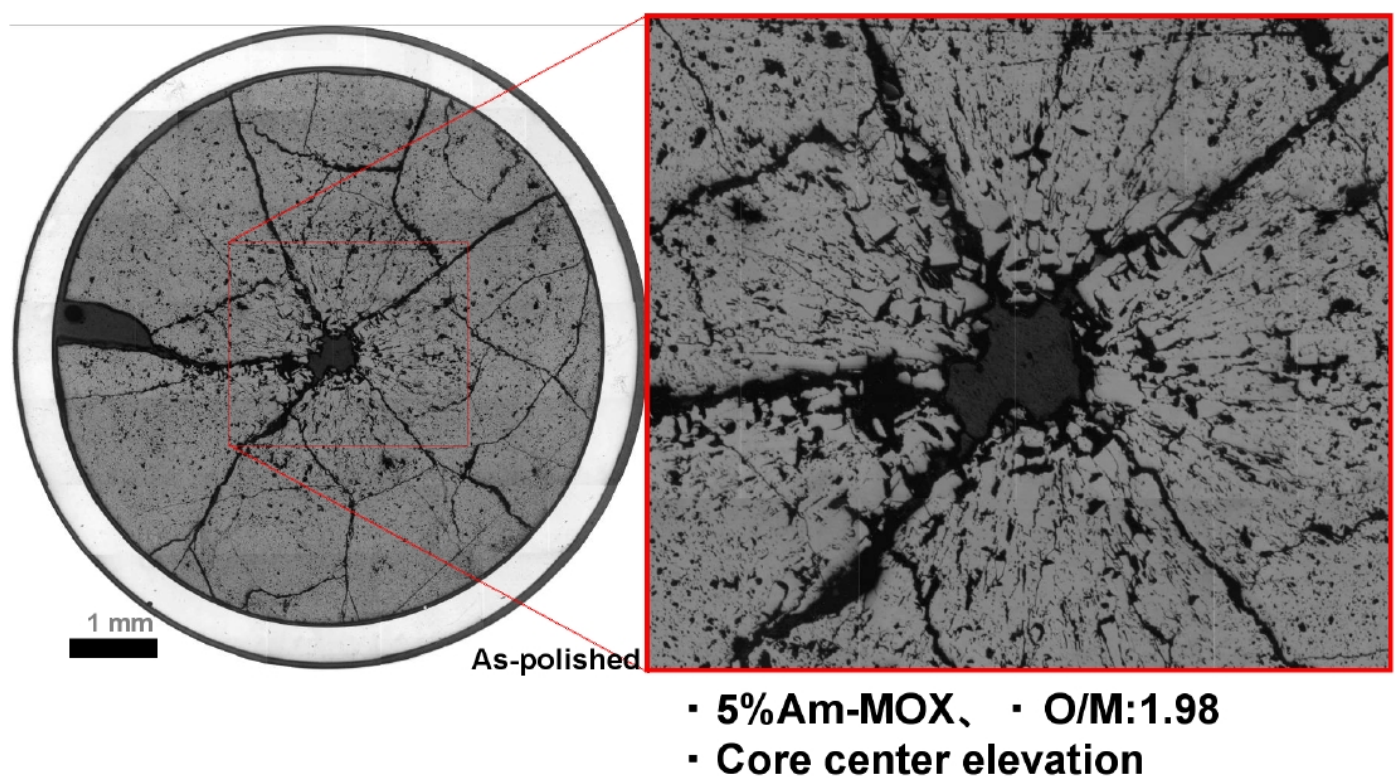

Figure 1. Photomicrograph of 5\% Am-MOX fuel from the AM-1 10-minute irradiation in Joyo ${ }^{49}$.

\subsubsection{AFC-2C, AFC-2D Oxide Transmutation Fuel}

Currently, the GNEP TRU Fuel Development Campaign (TFC) is fabricating a TRU-bearing oxide fuel test designated AFC-2C and AFC-2D. This test will initiate the testing of fast reactor mixed oxide (MOX)-based fuels in the ATR. The sibling capsules will each contain two rodlets each of three compositions: a baseline fast reactor MOX, a baseline MOX with minor actinides, and a baseline MOX with minor actinides and an oxygen-to-metal $(\mathrm{O} / \mathrm{M})$ variant. Because of the longer lead time for fabrication of MOX fuels for the AFC-2C and AFC-2D capsules, only one conversion ratio (CR) composition will be tested initially (i.e., 20\% plutonium will be tested first, corresponding to a CR of 0.6). The $\mathrm{O} / \mathrm{M}$ ratio is expected to be an important variable for TRU-bearing MOX fuel performance. More irradiation experiments will need to be conducted to gain a better understanding of the effect of minor actinide content on the $\mathrm{O} / \mathrm{M}$ ratio. An $\mathrm{O} / \mathrm{M}$ ratio of 1.98 was selected as the baseline with an $\mathrm{O} / \mathrm{M}$ ratio of 1.95 as an important variant. Table 2 provides a summary of the planned AFC-2C and D test compositions.

Table 2. AFC-2 C and D compositions.

\begin{tabular}{|c|l|}
\hline Rodlet & \multicolumn{1}{|c|}{$\begin{array}{c}\text { AFC-2C, AFC-2D } \\
\text { Fuel Test Matrix } \dagger\end{array}$} \\
\hline 1 & $\left(\mathrm{U}_{0.75}, \mathrm{Pu}_{0.2}, \mathrm{Am}_{0.03}, \mathrm{~Np}_{0.02}\right) \mathrm{O}_{1.95}$ \\
\hline 2 & $\left(\mathrm{U}_{0.8}, \mathrm{Pu}_{0.2}\right) \mathrm{O}_{1.98}$ \\
\hline 3 & $\left(\mathrm{U}_{0.75}, \mathrm{Pu}_{0.2}, \mathrm{Am}_{0.03}, \mathrm{~Np}_{0.02}\right) \mathrm{O}_{1.98}$ \\
\hline 4 & $\left(\mathrm{U}_{0.75}, \mathrm{Pu}_{0.2}, \mathrm{Am}_{0.03}, \mathrm{~Np}_{0.02}\right) \mathrm{O}_{1.95}$ \\
\hline 5 & $\left(\mathrm{U}_{0.8}, \mathrm{Pu}_{0.2}\right) \mathrm{O}_{1.98}$ \\
\hline 6 & $\left(\mathrm{U}_{0.75}, \mathrm{Pu}_{0.2}, \mathrm{Am}_{0.03}, \mathrm{~Np}_{0.02}\right) \mathrm{O}_{1.98}$ \\
\hline
\end{tabular}

$\dagger$ Fuel composition expressed in mole fraction. 
AFC-2C and AFC-2D are scheduled for ATR insertion in late-2008. The target burnup for AFC-2C is approximately 10 at.\%; the target burnup for AFC-2D is approximately 25 at. $\%$.

\subsubsection{JOYO Irradiation Tests in support of GNEP Oxide Fuel Compositions}

The U.S.-DOE GNEP TFC is currently negotiating with JAEA and JOYO test reactor operations for the conduct of transuranic fuel testing in the Joyo sodium-cooled fast-spectrum test reactor located in Oarai, Japan. Table 3 shows the currently proposed oxide fuel compositions. Note that these compositions are identical or very similar to the compositions currently under irradiation in the AFC-2 series of tests described earlier.

Table 3. Proposed oxide compositions for Joyo.

\begin{tabular}{|c|l|}
\hline Rodlet & \multicolumn{1}{|c|}{ Fuel Test Matrix $\uparrow$} \\
\hline 1 & $\left(\mathrm{U}_{0.75}, \mathrm{Pu}_{0.2}, \mathrm{Am}_{0.03}, \mathrm{~Np}_{0.02}\right) \mathrm{O}_{1.98}$ \\
\hline 2 & $\left(\mathrm{U}_{0.75}, \mathrm{Pu}_{0.2}, \mathrm{Am}_{0.03}, \mathrm{~Np}_{0.02}\right) \mathrm{O}_{1.95}$ \\
\hline 3 & $\left(\mathrm{U}_{0.62}, \mathrm{Pu}_{0.3}, \mathrm{Am}_{0.05}, \mathrm{~Np}_{0.03}\right) \mathrm{O}_{1.98}$ \\
\hline 4 & $\left(\mathrm{U}_{0.62}, \mathrm{Pu}_{0.3}, \mathrm{Am}_{0.05}, \mathrm{~Np}_{0.03}\right) \mathrm{O}_{1.95}$ \\
\hline 5 & $\left(\mathrm{U}_{0.75}, \mathrm{Pu}_{0.2}, \mathrm{Am}_{0.03}, \mathrm{~Np}_{0.02}\right) \mathrm{O}_{1.95}$ (Cladding Variant) \\
\hline
\end{tabular}

$\uparrow$ Fuel composition expressed in mole fraction.

\subsection{MA-Bearing Metal Transmutation Fuels}

Considering the demonstrated excellent performance of metal fuels, metal fuel provides the potential for performance as a TRU fuel depending on resolution of the following issues:

- Demonstration of group TRU oxide feedstock reduction to metal alloy feedstock. It is expected that the group TRU feedstock available for fuel fabrication will be in oxide form. This feedstock must be reduced to metal alloy for fuel fabrication.

- Due to Am metal volatility, fabrication with high Am retention must be demonstrated using quick melt and casting technologies.

- Metal fuel properties must not be seriously degraded from the U-Pu-Zr system performance by the addition of transuranics.

- Demonstration of an acceptable level of fuel cladding chemical interaction with fuel that includes rare earth impurities and TRU fuel constituents over the lifetime of the fuel up to its burnup limit, $\sim 20$ at. $\%$.

- Behavior of TRU fuel under run-beyond-design conditions, over-power transients, and run-beyondclad breach must be determined.

- Burnup upwards of $238 \mathrm{MWd} / \mathrm{kgM}$ (at $39 \times 10^{22} \mathrm{n} / \mathrm{cm}^{2}$ or approximately $200 \mathrm{dpa}$ ) can be anticipated with ferritic/martensitic steel cladding and up to $300 \mathrm{MWd} / \mathrm{kg}$ may be achievable with cladding materials with increased high temperature strength. ${ }^{3}$

An important question related to the use of U-Pu-Am-Np-Cm-Zr alloys as transmutation fuels are the unknown phase equilibria in the multi-component alloy system. The potential for immiscibility and formation of an inhomogeneous microstructure is not a fuel performance issue, as shown by the excellent performance of multi-phase U-Pu-Zr fuel. ${ }^{49}$ Rather, the formation of low melting phases in the complex alloy system is an issue that must be experimentally determined. Recent experimental irradiations and out-of-pile studies conducted as part of the AFCI program indicate that this is not an issue. 
Recycling technology for metal fuel has been established by electrochemical on an engineering scale. Remote fabrication was established as part of the EBR-II development program in the 1960s with the remote fabrication of more than 39,000 fuel pins in the Fuel Cycle Facility in Idaho.

Three transuranic metal fuel tests have been conducted, EBR-II X501, AFC1, and METAPHIX. The issues relevant to TRU metal alloy fuel fabrication and irradiation performance known from these experiments are presented below.

\subsubsection{X501 U-Pu-Zr-Am-Np Metal Fuel Experiment}

The X501 experiment was conducted in EBR-II as part of the IFR program to demonstrate minor actinide burning through the use of a homogeneous recycle scheme. The X501 subassembly contained two metal fuel elements loaded with $1.2 \mathrm{wt} . \%$ americium and $1.3 \mathrm{wt} . \%$ neptunium. Fuel slugs were fabricated by using differential pressure injection casting. Details of the casting process and resulting microstructure are given by Hofman and Walters ${ }^{50}$. Considerable americium was lost due to volatilization during the fabrication process, which was not designed for use with Am-bearing alloys. The X501 subassembly was inserted into EBR-II beginning in February 1993, and withdrawn just prior to EBR-II shutdown in August 1994 for a total irradiation time of 339 EFPDs. Burnup, calculated on the basis of REBUS/RCT/ORIGEN calculations, ${ }^{51}$ was $7.6 \% \mathrm{HM}$ with transmutation of $9.1 \%$ of ${ }^{241} \mathrm{Am}$. Peak linear heat generation rate was estimated to be $45 \mathrm{~kW} / \mathrm{m}(13.7 \mathrm{~kW} / \mathrm{ft})$ and peak fuel centerline and cladding inner surface temperatures were approximately $700^{\circ} \mathrm{C}$ and $540^{\circ} \mathrm{C}$, respectively. A partial Post-irradiation examination was completed on X501, including gamma scanning, optical microscopy, microprobe analysis, and metallography. An examination of the inside cladding surface was made to determine if the inclusion of the MA's to U-Pu-Zr fuel had an effect on FCCI (fuel-cladding chemical interaction). The HT-9 cladding used for the X501 experiment is also the reference cladding for U.S. transmutation fuel. Optical microscopy showed no evidence of reaction layer formation on the inner cladding wall or the outer surface of the fuel slug. A gap is visible between the fuel and the cladding wall at all locations. These preliminary results indicate that under typical metal fuel operating conditions, FCCI of HT-9 is not strongly affected by small amounts of americium or neptunium. Irradiated fuel shows a microstructure typical of $\mathrm{U}-20 \mathrm{Pu}-10 \mathrm{Zr}$, where constituent radial redistribution has resulted in the formation of three microstructural zones within the fuel. The X501 experiment demonstrated the acceptable behavior of $\mathrm{U}-\mathrm{Pu}-\mathrm{Zr}$ fuel with small but significant additions of americium and neptunium to intermediate burnup.

\subsubsection{AFC Irradiation Test Series}

Prior to irradiation experiments, considerable fabrication process development and characterization are performed for metal fuels. Typically such efforts are arranged through irradiation campaigns. The domestic irradiation campaigns are conducted in the Advanced Test Reactor (ATR) using a cadmium filter to reduce the thermal neutron flux. Those campaigns are named the AFC series and summarized below. In addition, a collaborative irradiation in the French Phénix reactor (referred to as the FUTURIX-FTA experiment) also is summarized below.

\subsubsection{AFC-1B and AFC-1D Non-Fertile Metal Fuel}

AFC-1B and AFC-1D contained metal fuel compositions of non-fertile fuels. A baseline composition, $\mathrm{Pu}-40 \mathrm{Zr}$, was included in the fuel test matrix as a comparison to evaluate the separate effects caused by the minor actinides. Both capsules began irradiation in ATR in June 2003. AFC-1B was discharged in February 2004 with a calculated peak burnup of 7.83 at.\%. AFC-1D was discharged from ATR in April 2007 with a calculated peak burnup of 39.5 at.\%. Table 4 shows a summary of compositions tested in the AFC-1B and AFC-1D test series. 
Table 4. AFC-1B and 1D compositions.

\begin{tabular}{|c|l|c|}
\hline Rodlet & $\begin{array}{c}\text { AFC-1B \& AFC-1D } \\
\text { Fuel Test Matrix } \uparrow\end{array}$ & $\begin{array}{c}\text { AFC-1B Discharge } \\
\text { Burnup (at.\%) * }\end{array}$ \\
\hline 1 & $\mathrm{Pu}-12 \mathrm{Am}-40 \mathrm{Zr}$ & 4.62 \\
\hline 2 & $\mathrm{Pu}-10 \mathrm{Am}-10 \mathrm{~Np}-40 \mathrm{Zr}$ & 6.13 \\
\hline 3 & $\mathrm{Pu}-40 \mathrm{Zr}$ & 6.59 \\
\hline 4 & $\mathrm{Pu}-12 \mathrm{Am}-40 \mathrm{Zr}$ & 6.80 \\
\hline 5 & $\mathrm{Pu}-60 \mathrm{Zr}$ & 7.83 \\
\hline
\end{tabular}

$\uparrow$ Alloy composition expressed in weight percent.

* Calculated burnup defined as percent of initial ${ }^{239} \mathrm{Pu}$ depleted.

Results from postirradiation examination of the fuel rodlets from the AFC-1B capsule show that, when correlated with fuel fission density, the major irradiation performance variables of these non-fertile fuels are in essential agreement with the historic database for $\mathrm{U}-\mathrm{Zr}$ and $\mathrm{U}-\mathrm{Pu}-\mathrm{Zr}$ fuels. Although the onset of fuel swelling and fission gas release may be slightly delayed, these phenomena appear to have converged with historic trend lines at approximately 8 at.\% burnup. Although irradiation performance of these fuels tracks with the historic database as a function of fission density, these less-dense TRU-bearing fuels reach a substantially higher burnup at a given fission density when compared to the much denser $\mathrm{U}-10 \mathrm{Zr}$ and $\mathrm{U}-20 \mathrm{Pu}-10 \mathrm{Zr}$ non-fertile fuels previously used. Thus, the present TRU-bearing metallic fuels with elevated levels of zirconium may be capable of a much higher burnup than the traditional metallic alloys. Figure 2 shows some metallographic samples of the PIE results.

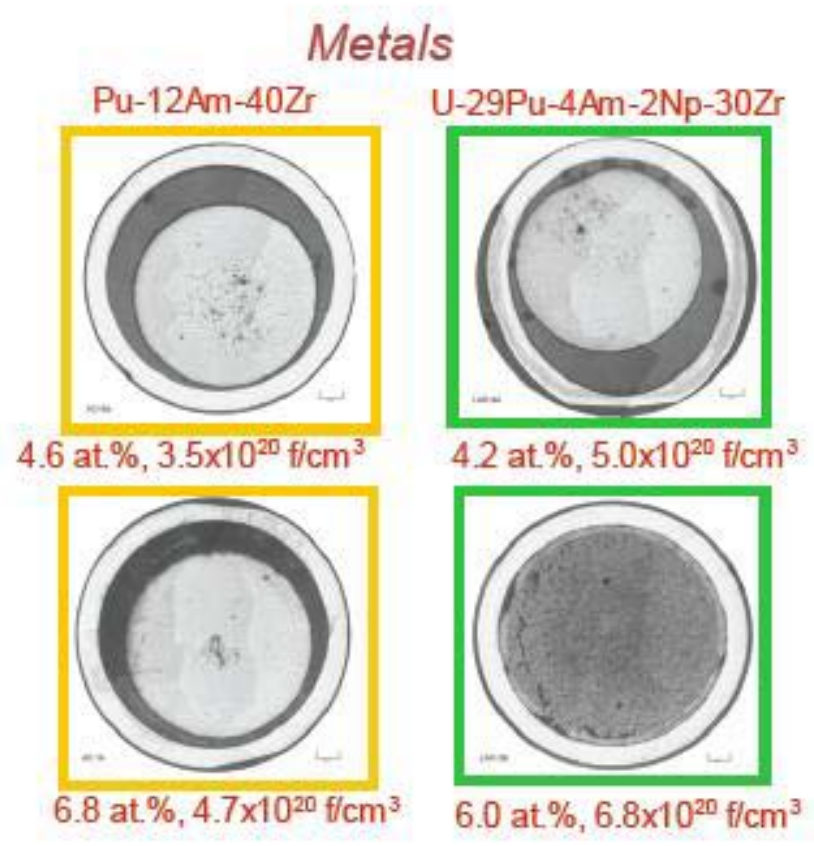

Figure 2. PIE results of TRU-bearing metallic fuels from the AFC-1B and AFC-1D irradiation experiments. 


\subsubsection{AFC-1F and AFC-1H Low-Fertile Metal Fuel}

Low-fertile metal fuel compositions were included in the AFC-1F and AFC-1H irradiation capsules. The plutonium content ranged from 25 to 34 weight percent and the zirconium content ranged from 20 to 40 weight percent. The irradiation of AFC-1F began in December 2003 and irradiation of AFC-1H began in July 2005. AFC-1F was discharged from ATR in April 2004 with a calculated peak burnup of 7.13 at.- $\%$. Capsule AFC-1H, currently under irradiation in ATR with a target discharge burnup of 35-40 at.- $\%$, is expected to be discharged by the end of 2007 . Table 5 provides a summary of the metal fuel compositions tested in AFC-1F and AFC-1H.

Table 5. AFC-1F and $1 \mathrm{H}$ compositions.

\begin{tabular}{|c|l|c|}
\hline Rodlet & \multicolumn{1}{|c|}{$\begin{array}{c}\text { AFC-1F \& AFC-1H } \\
\text { Fuel Test Matrix } \uparrow\end{array}$} & $\begin{array}{c}\text { AFC-1F Discharge } \\
\text { Burnup (at.\%) }\end{array}$ \\
\hline 1 & U-29Pu-4Am-2Np-30Zr & 4.28 \\
\hline 2 & U-34Pu-4Am-2Np-20Zr & 5.07 \\
\hline 3 & U-25Pu-3Am-2Np-40Zr & 7.13 \\
\hline 4 & U-29Pu-4Am-2Np-30Zr & 6.15 \\
\hline 5 & U-28Pu-7Am-30Zr & 6.05 \\
\hline 6 & U-25Pu-3Am-2Np-40Zr & 5.50 \\
\hline
\end{tabular}

$\dagger$ Alloy composition expressed in weight percent.

* Calculated burnup defined as percent of initial ${ }^{235} \mathrm{U}+{ }^{239} \mathrm{Pu}$ depleted.

As with the results from AFC-1B, results from PIE of the fuel rodlets from the AFC-1F capsule show that, when correlated with fuel fission density, the major irradiation performance variables of these non-fertile fuels are in essential agreement with the historic database for $\mathrm{U}-\mathrm{Zr}$ and $\mathrm{U}-\mathrm{Pu}-\mathrm{Zr}$ fuels.

\subsubsection{AFC-2A and AFC-2B Metal Transmutation Fuel}

AFC-2A and AFC-2B irradiation experiments are a continuation of the metal test series started in AFC-1. These experiments consist of metal fuel alloys of $\mathrm{U}, \mathrm{Pu}, \mathrm{Np}, \mathrm{Am}$, and $\mathrm{Zr}$. Some of the rodlets in the AFC-2A and AFC-2B experiments contain rare earth elements designed to simulate potential FP carry-over from fast reactor recycling processes. Table 6 provides a summary of the fuel compositions currently under testing in AFC-2A and AFC-2B.

Table 6. AFC-2 A and B compositions.

\begin{tabular}{|c|l|}
\hline Rodlet & \multicolumn{1}{|c|}{$\begin{array}{c}\text { AFC-2A, AFC-2B } \\
\text { Fuel Test Matrix }{ }^{\dagger}\end{array}$} \\
\hline 1 & $\mathrm{U}-20 \mathrm{Pu}-3 \mathrm{Am}-2 \mathrm{~Np}-15 \mathrm{Zr}$ \\
\hline 2 & $\mathrm{U}-20 \mathrm{Pu}-3 \mathrm{Am}-2 \mathrm{~Np}-1.0 \mathrm{RE}^{*}-15 \mathrm{Zr}$ \\
\hline 3 & $\mathrm{U}-20 \mathrm{Pu}-3 \mathrm{Am}-2 \mathrm{~Np}-1.5 \mathrm{RE}^{*}-15 \mathrm{Zr}$ \\
\hline 4 & $\mathrm{U}-30 \mathrm{Pu}-5 \mathrm{Am}-3 \mathrm{~Np}-1.5 \mathrm{RE}^{*}-20 \mathrm{Zr}$ \\
\hline 5 & $\mathrm{U}-30 \mathrm{Pu}-5 \mathrm{Am}-3 \mathrm{~Np}-1.0 \mathrm{RE}^{*}-20 \mathrm{Zr}$ \\
\hline 6 & $\mathrm{U}-30 \mathrm{Pu}-5 \mathrm{Am}-3 \mathrm{~Np}-20 \mathrm{Zr}$ \\
\hline
\end{tabular}

$\dagger$ Alloy composition expressed in weight percent.

$*$ RE designates rare earth alloy (6\% La, $16 \% \mathrm{Pr}, 25 \% \mathrm{Ce}, 53 \% \mathrm{Nd})$.

The two capsules, AFC-2A and AFC-2B, are designed as sibling tests. Each capsule will have the same set of rodlets with identical compositions, but each capsule will have a different target discharge 
burnup. The target discharge burnup for capsule AFC-2A is 10 at.\% and for capsule AFC-2B is 25 at. $\%$. By irradiating two identical capsules to two different burnups, fuel performance phenomena as a function of burnup can be investigated. Furthermore, high burnup fuels are of interest to the transmutation fuel development program and irradiating advanced fuels to high burnups provides valuable information regarding the life of the fuel, as well as exploring the potentially life-limiting phenomena in these TRU-bearing metallic fuels. Insertion of capsules AFC-2A and AFC-2B into ATR was performed in October 2007.

\subsubsection{FUTURIX-FTA}

In conjunction with the AFC test series as discussed above, a series of test compositions has been placed in the fast spectrum Phénix reactor in May 2007 as part of the FUTURIX-FTA irradiation.

The U.S. supplied two metallic fuel pins with U-29Pu-4Am-2Np-30Zr and $\mathrm{Pu}-12 \mathrm{Am}-40 \mathrm{Zr}$ as fuel alloys, and two nitride fuel pins with $\left(\mathrm{U}_{0.50}, \mathrm{Pu}_{0.25}, \mathrm{Am}_{0.15}, \mathrm{~Np}_{0.10}\right) \mathrm{N}$ and $\left(\mathrm{Pu}_{0.32}, \mathrm{Am}_{0.32}, \mathrm{Zr}_{0.36}\right) \mathrm{N}$ as fuel compositions. The Commissariat a l'Energie Atomique (CEA) supplied two oxide fuel pins with $\left(\mathrm{Pu}_{0.50}, \mathrm{Am}_{0.50}\right) \mathrm{O}_{2}$ in $80 \mathrm{vol} \%-\mathrm{MgO}$ and $\left(\mathrm{Pu}_{0.20}, \mathrm{Am}_{0.80}\right) \mathrm{O}_{2}$ in $75 \mathrm{vol} \%-\mathrm{MgO}$ as fuel compositions. The Institute of Transuranium Elements (ITU) supplied two cermet fuel pins with $\left(\mathrm{Pu}_{0.80}, \mathrm{Am}_{0.20}\right) \mathrm{O}_{2}$ in 86 vol\%-Mo and $\left(\mathrm{Pu}_{0.23}, \mathrm{Am}_{0.25}, \mathrm{Zr}_{0.52}\right) \mathrm{O}_{2}$ in 60 vol\%-Mo as fuel compositions. Table 7 provides a summary of the fuel compositions in the FUTURIX-FTA test.

Table 7. Summary of test compositions in FUTURIX-FTA.

\begin{tabular}{|c|l|}
\hline Supplier & \multicolumn{1}{|c|}{$\begin{array}{c}\text { FUTURIX-FTA } \\
\text { Fuel Compositions } \uparrow\end{array}$} \\
\hline U.S. & $35 \mathrm{U}-29 \mathrm{Pu}-4 \mathrm{Am}-2 \mathrm{~Np}-30 \mathrm{Zr}$ \\
\hline U.S. & $48 \mathrm{Pu}-12 \mathrm{Am}-40 \mathrm{Zr}$ \\
\hline U.S. & $\left(\mathrm{U}_{0.50}, \mathrm{Pu}_{0.25}, \mathrm{Am}_{0.15}, \mathrm{~Np}_{0.10}\right) \mathrm{N}$ \\
\hline U.S. & $\left(\mathrm{Pu}_{0.32}, \mathrm{Am}_{0.32}, \mathrm{Zr}_{0.36}\right) \mathrm{N}$ \\
\hline CEA & $\left(\mathrm{Pu}_{0.50}, \mathrm{Am}_{0.50}\right) \mathrm{O}_{2}$ in 80 vol\%-MgO \\
\hline CEA & $\left(\mathrm{Pu}_{0.20}, \mathrm{Am}_{0.80}\right) \mathrm{O}_{2}$ in 75 vol\%-MgO \\
\hline ITU & $\left(\mathrm{Pu}_{0.80}, \mathrm{Am}_{0.20}\right) \mathrm{O}_{2}$ in 86 vol\%-Mo \\
\hline ITU & $\left(\mathrm{Pu}_{0.23}, \mathrm{Am}_{0.25}, \mathrm{Zr}_{0.52}\right) \mathrm{O}_{2}$ in 60 vol\%-Mo \\
\hline
\end{tabular}

$\dagger$ Metallic alloy composition expressed in weight percent.

Ceramic alloy composition expressed in mole percent.

The metal and oxide fuel compositions began irradiation in Phénix in May 2007. The nitride fuel compositions have not yet been inserted. Additional assessment of the nitride fuels in terms of mechanical integrity and chemical impurities continue, with a possible insertion in Spring 2008. All fuel compositions are scheduled to be discharged in Spring 2009.

\subsubsection{METAPHIX}

The METAPHIX set of experiments is being conducted as a collaboration between the Central Research Institute of Electric Power Industry (CRIEPI) and ITU with support from CEA in the Phénix fast test reactor located in France. It consists of U-Pu-Zr metal fuel base compositions containing transuranics, including $\mathrm{Am}, \mathrm{Np}$, and $\mathrm{Cm}$, and lanthanides. This experiment will provide substantial data on the performance of TRU metal fuels containing lanthanides and minor actinides under fast reactor irradiation conditions. There are three assemblies (METAPHIX-1, 2, and 3) irradiated to burnups of $\sim 2.5$, 
$\sim 7$, and $\sim 11$ at.\%, respectively. The first two were discharged from the Phénix reactor in August 2004, and in July 2007 and some examinations have been performed. ${ }^{53}$ No fuel failures have been observed. ${ }^{54}$

\subsubsection{Joyo Irradiation Tests in Support of GNEP Metal Alloy Fuel Compositions}

The USDOE GNEP TFC is currently negotiating with JAEA and Joyo test reactor operations for the conduct of transuranic fuel testing in the Joyo sodium-cooled fast-spectrum test reactor located in Oarai, Japan. Table 8 shows the currently proposed metal alloy and oxide fuel compositions. Note that these compositions are identical or very similar to the compositions currently under irradiation in the AFC-2 series of tests described above.

Table 8. Proposed metal alloy compositions for Joyo.

\begin{tabular}{|c|l|}
\hline Rodlet & \multicolumn{1}{|c|}{ Fuel Test Matrix $\dagger$} \\
\hline 1 & $\mathrm{U}-20 \mathrm{Pu}-3 \mathrm{Am}-2 \mathrm{~Np}-15 \mathrm{Zr}$ \\
\hline 2 & $\mathrm{U}-20 \mathrm{Pu}-3 \mathrm{Am}-2 \mathrm{~Np}-1.5 \mathrm{RE}^{*}-15 \mathrm{Zr}$ \\
\hline 3 & $\mathrm{U}-30 \mathrm{Pu}-5 \mathrm{Am}-3 \mathrm{~Np}-20 \mathrm{Zr}$ \\
\hline 4 & $\mathrm{U}-30 \mathrm{Pu}-5 \mathrm{Am}-3 \mathrm{~Np}-1.5 \mathrm{RE}^{*}-20 \mathrm{Zr}$ \\
\hline 5 & $\mathrm{U}-30 \mathrm{Pu}-20 \mathrm{Zr}$ (Cladding Variant) \\
\hline
\end{tabular}

$\dagger$ Alloy composition expressed in weight percent.

* RE designates rare earth alloy (6\% La, $16 \% \mathrm{Pr}, 25 \% \mathrm{Ce}, 53 \% \mathrm{Nd})$.

\subsubsection{KAERI-10 US-Korean Collaboration}

The Korea Atomic Energy Research Institute (KAERI) and Idaho National Laboratory (INL) are collaborating on a wide range of topics within the broad subject of spent nuclear fuel processing under the KAERI-10 agreement. More specifically, both organizations have active research programs that are currently developing electrochemical spent fuel processing technology. The objective of such dry processing technology is to remove fission products from spent nuclear fuel and enable its refabrication into new fuel. Unlike the wet-chemical based PUREX method, this is a nuclear proliferation-resistant process. Electrochemical spent fuel treatment technology is not designed to separate $\mathrm{Pu}$ from other actinides. The product from the process is a group of actinides-including $\mathrm{U}, \mathrm{Pu}, \mathrm{Am}, \mathrm{Np}$, and $\mathrm{Cm}$. Such a mixture of actinides is relatively unattractive for nuclear proliferation.

The KAERI-10 project is currently organized into 5 tasks:

A. Assessment of Low-Level Waste (LLW) Characteristics of Uranium Product

B. Electrorefiing Experiments with Graphite Cathodes

C. Group Actinide Recovery Experiments

D. Integrated Demonstration of Metal Ternary Fuel Fabrication from Processing Spent LWR Fuel

E. Process Modeling and Graphical Simulation of a Pyroprocessing-based Fuel Cycle Facility. 


\subsection{MA-Bearing Nitride Transmutation Fuels}

TRU-bearing nitride fuels have been under study in the AFCI program. They are also of interest to international fuel development programs because they may provide a high thermal conductivity fuel with a high fuel density and a high melting temperature. The use of nitride TRU fuel is considered to be in the early stages of composition definition. The following issues must be resolved for transuranic nitride composition fuel to be viable:

- Demonstration of fabrication techniques resulting in adequate fuel density at moderate sintering temperatures or development of novel low temperature fabrication techniques capable of retaining Am content during densification.

- Resolution of extensive cracking and fragmentation during irradiation.

- $\quad \mathrm{N}-15$ enrichment process must be developed having suitable economics.

The AFCI fuel development program has experienced difficulty in fabricating robust fuel pellets, evidenced by fuel fragmentation and extensive macro-cracking upon irradiation. Nitride fuel systems require further fabrication development to optimize process parameters.

A number of TRU-bearing nitride fuel compositions containing various quantities of $\mathrm{U}-\mathrm{Pu}-\mathrm{N}$, and the minor actinides have been tested in HT-9 cladding in the Advanced Test Reactor as part of the ATW and AFC series of irradiations under the AFCI program. The nitride fuel compositions have exhibited fabrication related cracking and fragmentation upon irradiation. This has lead to some fuel relocation but neither fuel-clad interactions nor failures have been observed. ${ }^{55}$

Similar to the metal alloy fuel in the AFC test series, a series of nitride test compositions will be placed in the fast spectrum Phénix reactor in the mid-2008 timeframe as part of the FUTURIX-FTA irradiation.

\subsubsection{AFC-1/E Non- and Low-Fertile Nitride Fuel}

Irradiation capsule AFC- $1 \nRightarrow$ (a combination of planned tests AFC-1A and AFC-1E) consisted of four non-fertile and one low-fertile fuel rodlets. In addition to plutonium, three rodlets contained americium and two rodlets contained americium and neptunium. AFC-1Æ was inserted into ATR in December 2003 and discharged in April 2004. The peak rodlet in the capsule achieved a calculated discharge burnup of 7.85 at.\%. Table 9 provides a summary of the AFC- $1 Æ$ nitride fuel test compositions.

Table 9. AFC-1 AE nitride compositions.

\begin{tabular}{|c|l|c|}
\hline Rodlet & AFC-1 $Æ$ Fuel Test Matrix $\dagger$ & Discharge Burnup (at.\%)* \\
\hline 1 & $\left(\mathrm{Pu}_{0.5}, \mathrm{Am}_{0.5}\right) \mathrm{N}-36 Z r N$ & 5.09 \\
\hline 2 & $\mathrm{DUMMY}$ & $\mathrm{n} / \mathrm{a}$ \\
\hline 3 & $\left(\mathrm{Pu}_{0.5}, \mathrm{Am}_{0.5}\right) \mathrm{N}-36 \mathrm{ZrN}$ & 7.45 \\
\hline 4 & $\left(\mathrm{Pu}_{0.5}, \mathrm{Am}_{0.5}\right) \mathrm{N}-36 \mathrm{ZrN}$ & 7.85 \\
\hline 5 & $\left(\mathrm{Pu}_{0.5}, \mathrm{Am}_{0.25}, \mathrm{~Np}_{0.25}\right) \mathrm{N}-36 \mathrm{ZrN}$ & 7.49 \\
\hline 6 & $\left(\mathrm{U}_{0.5}, \mathrm{Pu}_{0.25}, \mathrm{Am}_{0.15}, \mathrm{~Np}_{0.10}\right) \mathrm{N}$ & 4.40 \\
\hline
\end{tabular}

$\dagger$ Actinide content expressed in mole fraction and zirconium nitride content expressed in weight percent.

*Calculated burnup defined as percent of initial ${ }^{239} \mathrm{Pu}$ depleted. 
The AFC-1Æ nitride transmutation fuel compositions examined to date following irradiation in ATR have been observed to be low-swelling, low-gas release fuels, which is in agreement with limited data on (U,Pu)N fuels from the past. Extensive cracking, fragmentation and some relocation of the nitride pellets were observed to occur during irradiation, which may limit the burnup capability of this fuel form. Sample PIE results for the nitride fuels are shown in Figure 2.

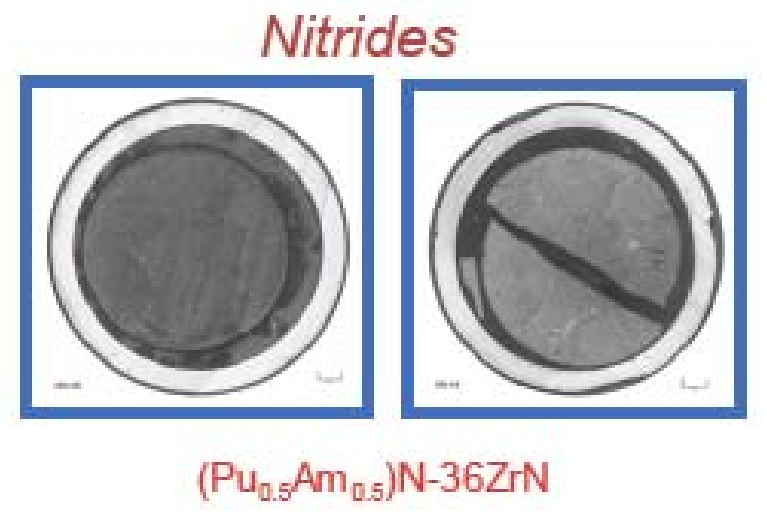

Figure 2. Sample PIE results of TRU-bearing nitride fuels.

\subsubsection{AFC-1G Low-Fertile Nitride and Non-Fertile Metallic Fuel}

Irradiation test AFC-1G was planned as a high burnup nitride test, but fabrication difficulties resulted in only one available rodlet for irradiation. Two spare rodlets of metal fuel were added to the capsule for irradiation in ATR. The target discharge burnup for capsule AFC-1G is approximately 20 at. $\%$ for the nitride rodlet (Rodlet 3) with an acceptable limit for the metal rodlets (Rodlets 1 and 4 ) of up to 40 at.\%. Irradiation capsule AFC-1G is still undergoing irradiation in ATR with discharge expected by the end of 2008. Table 10 provides a summary of the AFC-1G test compositions.

Table 10. AFC-1 G Nitride and non-fertile metal compositions.

\begin{tabular}{|c|l|}
\hline Rodlet & \multicolumn{1}{|c|}{ AFC-1G Fuel Test Matrix } \\
\hline 1 & $\mathrm{Pu}-10 \mathrm{~Np}-40 \mathrm{Zr} \dagger$ \\
\hline 2 & $\mathrm{DUMMY}$ \\
\hline 3 & $\left(\mathrm{U}_{0.50}, \mathrm{Pu}_{0.25}, \mathrm{Am}_{0.15}, \mathrm{~Np}_{0.10}\right) \mathrm{N} *$ \\
\hline 4 & $\mathrm{Pu}-10 \mathrm{~Np}-40 \mathrm{Zr} \dagger$ \\
\hline
\end{tabular}

$\uparrow$ Alloy composition expressed in weight percent.

* Fuel composition expressed in mole fraction.

\subsection{MA-Bearing Carbide Transmutation Fuels}

Carbide fuel provides less potential for use as a TRU fuel than the above fuel systems due to the following issues that require resolution:

- Carbide fuel was still in the developmental stage at the termination of carbide fuel development programs two decades ago. The operating envelope for carbide fuel is not as well established as that for oxide and metal fuel.

- Although some research has been performed on recycling of carbides, the technology has not been demonstrated on an appreciable scale.

- Due to Am metal volatility, fabrication with high Am retention must be demonstrated.

- Very little is known about TRU carbides, and fuel properties must not be seriously degraded from the $\mathrm{U}, \mathrm{Pu}, \mathrm{Zr}$ system performance by the addition of transuranics. 
- Demonstration of an acceptable level of fuel cladding mechanical interaction with fuel that includes rare earth impurities and TRU fuel constituents over the lifetime of the fuel up to its burnup limit, 20 at $\%$.

- Behavior of TRU carbide fuel under run-beyond-design conditions, over-power transients, and runbeyond-clad breach must be determined.

- Carbide fuel does not currently have a demonstration of an acceptable recycling process.

\subsection{MA-Bearing Dispersion Transmutation Fuels}

Two general concepts of a dispersion fuels area termed "CERCER," for ceramic particles embedded in a ceramic matrix and "CERMET," for ceramic particles embedded in a metal matrix. Dispersion fuels typically provide a robust fuel form capable of high burnup operation at high temperature with low fission gas release and low fission product swelling. An open question in the use of dispersion fuels is the ability to accommodate helium release due to americium and curium. The fabrication routes for dispersion fuels typically lend themselves for use in remote fabrication environments. A number of fuel development programs have utilized and studied dispersed fuel systems for TRU fuel applications, but no TRU bearing dispersion fuels have received significant irradiation testing.

\subsection{MA-Bearing Transmutation Targets}

Target fuel systems offer the benefit of elimination of fertile (breeding) isotopes (such as ${ }^{238} \mathrm{U}$ ) from the fuel matrix. These fuel forms receive attention for transmutation systems that use external neutron sources, such as accelerator driven systems, because they eliminate additional TRU production during irradiation and in some analyses provide the potential for high TRU destruction efficiency. Targets theoretically provide an effective transmutation system. The use of totally fertile-free fuels in the core region of fast reactors is not feasible due to the negative impact on safety parameters. However, targets may be used in a heterogeneous core that uses a more conventional (U-bearing) driver fuel. Because transuranics are separated as a group under the GNEP scenario, there are currently limited re-enrichment options using the group TRU feedstock. Targets require a suitable inert matrix material to replace the uranium and although several options are available none are proven. If pursued, this heterogeneous recycling option requires a different and (possibly more difficult) fuel development effort. In addition, the economics and TRU destruction rate of heterogeneous recycling schemes with group transuranics must be fully assessed. In addition, some new design work is being pursued by French researchers on the use of depleted uranium targets in the blanket region of fast reactors. ${ }^{56}$ This research is very preliminary and the use and feasibility is not yet proven but may provide another option for TRU destruction using non-traditional methods.

\subsubsection{ECRIX B and $\mathrm{H}$}

Another form of target that may be of interest in fast reactor transmutation applications would be the use of Am loaded targets in a thermalized region of the fast reactor blanket. This option requires that Am (or Am and $\mathrm{Cm}$ ) be separated from the other TRU elements, which will be used in the transmutation fuel. An example of this transmutation option would be the ECRIX experiment.

The goal of the ECRIX B and H experiments conducted in the Phénix fast test reactor, is to test the feasibility of the incineration of americium in heterogeneous mode in the context of monorecycling in fast reactors. Two identical experimental pins are placed in the reactor under different irradiation conditions. Inside each pin is a $200-\mathrm{mm}$ high column made of pellets holding americium oxide particles which are a few micrometers in diameter and are uniformly distributed in an inert magnesia matrix. 
These experiments are conducted inside a device capable of locally moderating the neutron flux using a thermalizing material (boron carbide and calcium hydride) as a shroud, in order to increase the effectiveness of the transmutation. The significant neutron flux available at Phénix can be used to advantage, in combining it with high cross-sections, accelerating the conversion of the americium and curium and promoting their disappearance, benefiting from the high fission cross-sections of the isotopes ${ }^{243} \mathrm{Cm}$ and ${ }^{245} \mathrm{Cm}$.

\subsubsection{MA-Bearing Sphere-Pac Oxide Fuel}

Remote fabrication of TRU oxide fuel has not been demonstrated using traditional oxide fabrication methods. Traditional fabrication methods may not be possible in a high radiation field. The sphere-pac fabrication process may provide the route to a viable oxide fuel composition that lends itself to fabrication in a remote fabrication environment. Sphere-pac fuel has been demonstrated in Russia in the BOR-60 fast spectrum reactor which is currently partially fueled with vibrationally compacted sphere-pac $(\mathrm{U}, \mathrm{Pu}) \mathrm{O}_{\mathrm{x}}$ fuel and achieves burnup levels on the order of 15 at. $\%{ }^{57}$

\section{REFERENCES}

1. W.J. Carmack and K.O. Pasamehmetoglu, "Definition of Technology Readiness Levels for Transmutation Fuel Development." Idaho National Laboratory External Report: INL/EXT-08-13780, GNEP-FUEL-FUEL-TD-RT-2008-000051. January 2008.

2. D. C. Crawford, D. L. Porter, and S. L. Hayes, "Fuels for Sodium-cooled Fast Reactors: U.S. Perspective," Journal of Nuclear Materials, submitted for publication, July 2006.

3. R. D. Leggett and L. C. Walters, "Status of LMR Fuel Development in the United States of America," Journal of Nuclear Materials, 204 (1993) 23-32.

4. R. G. Pahl, D. L. Porter, C. E. Lahm, and G. L. Hofman, "Experimental Studies of U-Pu-Zr Fast Reactor Fuel Pins in the Experimental Breeder Reactor-II," Metallurgical Transactions A, 21A (1990) 1863-1870.

5. R. G. Pahl, D. L Porter, D. C. Crawford, and L. C. Walters, "Irradiation Behavior of Metallic Fast Reactor Fuels," Journal of Nuclear Materials, 188 (1992) 3-9.

6. E. Bridges, A. E. Waltar, R. D. Leggett, and R. B. Baker, “A Liquid-Metal Reactor Core Demonstration Experiment Using HT9," Nuclear Technology, 102 (1993) 353-366.

7. R. B. Baker, F. E. Bard, R. D. Leggett, and A. L. Pitner, "Status of Fuel, Blanket, and Absorber Testing in the Fast Flux Test Facility," Journal of Nuclear Materials, 204 (1993) 109-118.

8. E. Wright, D. S. Dutt, and L. J. Harrison, "Fast Reactor Safety Testing in TREAT in the 1990s," International Fast Reactor Safety Meeting, Snowbird, Utah, 1990, American Nuclear Society, La Grange Park, IL, 233-243.

9. T. H. Bauer, A. E. Wright, W. R. Robinson, J. W. Holland, and E. A. Rhodes, "Behavior of Modern Metallic Fuel in TREAT Transient Overpower Tests," Nuclear Technology, 92 (1990) 325-352.

10. Y. Y. Liu, H. Tsai, M. C. Billone, J. W. Holland, and J. M. Kramer, "Behavior of EBR-II Mk-V-Type Fuel Elements in Simulated Loss-of-Flow Tests," Journal of Nuclear Materials, 204 (1993) 194-202.

11. C. J. Alderman and A. L Pitner, "Transient Testing of Long-Lifetime Mixed-Oxide Liquid-Metal Reactor Fuel," Transactions of the American Nuclear Society, 56 (1988) 382-383.

12. Tsai, L. A. Neimark, T. Asaga, and S. Shikakura, "Behavior of Mixed-Oxide Fuel Elements During an Overpower Transient," Journal of Nuclear Materials, 204 (1993) 217-227. 
13. L. Hofman and L. C. Walters, "Metallic Fast Reactor Fuels," from Nuclear Materials, Part I Volume 10 A, edited by B. R. T. Frost, appearing in Materials Science and Technology, A Comprehensive Treatment, edited by R. W. Cahn, P, Haasen, and E. J. Kramer, VCH Verlagsgesellschaft mbH, (1994) 1-43.

14. R. V. Strain, J. H. Bottcher, S. Ukai, and Y. Arii, "Fuel-Sodium Reaction Product and its Influence on Breached Mixed-Oxide Fuel Pins," Journal of Nuclear Materials, 204 (1993) 252-260.

15. M.A. Smith, R.N. Hill, M. Williamson, "Low Conversion Ratio Fuel Studies.” Argonne National Laboratory Report, ANL-AFCI-163. February 2006.

16. L. C. Walters, B. R. Seidel, and J, H, Kittel, "Performance of Metallic Fuels and Blankets in Liquid-Metal Fast Breeder Reactors,” Nuclear Technology, 65 (1984) 179-231.

17. H. Kittel, B. R. T. Frost, J. P. Mustellier, K. Q. Bagley, G. C. Crittenden, and J. Van Dievoet, "History of Fast Reactor Fuel Development," Journal of Nuclear Materials, 204 (1993) 1-13.

18. C. Walters, B. R. Seidel, and J, H, Kittel, "Performance of Metallic Fuels and Blankets in Liquid-Metal Fast Breeder Reactors,” Nuclear Technology, 65 (1984) 179-231.

19. H. Kittel, B. R. T. Frost, J. P. Mustellier, K. Q. Bagley, G. C. Crittenden, and J. Van Dievoet, "History of Fast Reactor Fuel Development," Journal of Nuclear Materials, 204 (1993) 1-13.

20. H. Kittel, B. R. T. Frost, J. P. Mustellier, K. Q. Bagley, G. C. Crittenden, and J. Van Dievoet, "History of Fast Reactor Fuel Development," Journal of Nuclear Materials, 204 (1993) 1-13.

21. C. E. Lahm, J. F. Koenig, R. G. Pahl, D. L. Porter, and D. C. Crawford, "Experience with Advanced Driver Fuels in EBR-II," Journal of Nuclear Materials, 204 (1993) 119-123.

22. L. Hofman and L. C. Walters, "Metallic Fast Reactor Fuels," from Nuclear Materials, Part I Volume 10 A, edited by B. R. T. Frost, appearing in Materials Science and Technology, A Comprehensive Treatment, edited by R. W. Cahn, P, Haasen, and E. J. Kramer, VCH Verlagsgesellschaft mbH, (1994) 1-43.

23. R. G. Pahl, D. L Porter, D. C. Crawford, and L. C. Walters, "Irradiation Behavior of Metallic Fast Reactor Fuels," Journal of Nuclear Materials, 188 (1992) 3-9.

24. see for example R.G. Pahl, R.S. Wisner, M.C. Billone, G.L. Hofman, "Steady State Irradiation Testing of U-Pu-Zr Fuel to $>18 \%$ Burnup," Proc. Int. Conf. on Fast Reactor Safety IV, Snowbird Utah, 12-16 August (1990).

25. L.C. Walters," Thirty Years of Fuels and Materials Information from EBR-II," J. Nucl. Mat., 270 (1999) 39-48.

26. "Fuel Test Plan', complied by D. L. Porter, Argonne National Laboratory, with contributions by Argonne National Laboratory, General Electric, and Westinghouse-Hanford Co., June, 1994.

27. L. Pitner, and R. B. Baker, "Metal Fuel Test Program in the FFTF," Journal of Nuclear Materials, 204 (1993) 124-130.

28. E. Wright, D. S. Dutt, and L. J. Harrison, "Fast Reactor Safety Testing in TREAT in the 1990s," International Fast Reactor Safety Meeting, Snowbird, Utah, 1990, American Nuclear Society, La Grange Park, IL, 233-243.

29. G. L. Hofman and L. C. Walters, "Metallic Fast Reactor Fuels," from Nuclear Materials, Part I Volume 10 A, edited by B. R. T. Frost, appearing in Materials Science and Technology, A Comprehensive Treatment, edited by R. W. Cahn, P, Haasen, and E. J. Kramer, VCH Verlagsgesellschaft mbH, (1994) 1-43. 
30. T. Sofu, J. M. Kramer, J. E. Cahalan, "SASSYS/SAS4A-FPIN2 Liquid-Metal Reactor Transient Analysis Code System for Mechanical Analysis of Metallic Fuel Elements," Nuclear Technology, 113 (1996) 268-279.

31. J. Miles, "Metal Fuel Safety Performance," in Proceedings of the International Topical Meeting in Safety of Next Generation Fast Reactors, Seattle, WA, May 1-5, 1988, American Nuclear Society, La Grange Park, IL, 119-124.

32. Y. Y. Liu, H. Tsai, M. C. Billone, J. W. Holland, and J. M. Kramer, "Behavior of EBR-II Mk-V-Type Fuel Elements in Simulated Loss-of-Flow Tests," Journal of Nuclear Materials, 204 (1993) 194-202.

33. M. Kramer, Y. Y. Liu, M. C. Billone, and H. C., Tsai, "Modeling the Behavior of Metallic Fast Reactor Fuels During Extended Transients," Journal of Nuclear Materials, 204 (1993) 203-211.

34. R. J. Neuhold, L. C. Walters, R. D. Leggett, and R. B. Matthews, "High Reliabilty Fuel in the US," Proceedings of the International Conference on Reliable Fuels for Liquid Metal Reactors, Tuscon, AZ, September 7-11, 1986, American Nuclear Society, La Grange Park, IL, 1-16 - 1-29.

35. R. B. Matthews and R. J. Herbst, "Uranium-Plutonium Carbide Fuel for Fast Breeder Reactors," Nuclear Technology, 63 (1983) 9-22.

36. G. R. Harry, U.S. Department of Energy Report LA-UR-83-1248 (1983).

37. R. J. Herbst and R. W. Stratton, "LMR Advanced Fuels - (U,Pu)-Carbide Fabrication, Performance and Reliability," Proceedings of the International Conference on Reliable Fuels for Liquid Metal Reactors, Tuscon, AZ, September 7-11, 1986, American Nuclear Society, La Grange Park, IL, 7-1 7-14.

38. R. E. Mason, C. W. Hoth, R. W. Stratton, and F. Botta, "Irradiation and Examination Results of the AC-3 Mixed Carbide Test,” Trans. Am. Nucl. Soc., 66 (1992), pp. 215-217.

39. R. J. Neuhold, L. C. Walters, R. D. Leggett, and R. B. Matthews, "High Reliabilty Fuel in the US," Proceedings of the International Conference on Reliable Fuels for Liquid Metal Reactors, Tuscon, AZ, September 7-11, 1986, American Nuclear Society, La Grange Park, IL, 1-16 - 1-29.

40. R. B. Matthews and R. J. Herbst, "Uranium-Plutonium Carbide Fuel for Fast Breeder Reactors," Nuclear Technology, 63 (1983) 9-22.

41. Hj. Matzke, Science of Advanced LMFBR Fuels, Elsevier Science Publishers, New York (1986) Chapter 10.

42. W. D. Leggett III and R. D. Leggett, "A Decade of Progress in Fast Reactor Fuel," in LMR: A Decade of LMR Progress and Promise, Washington, D.C, November 11-15, 1990, American Nuclear Society, La Grange Park, IL, 138-143.

43. W. F. Lyon, R. B. Baker, and R. D. Leggett, "Performance Analysis of a Mixed Nitride Fuel System for an Advanced Liquid Metal Reactor," in LMR: A Decade of LMR Progress and Promise, Washington, D.C, Nov 11-15, 1990, American Nuclear Society, La Grange Park, IL, 236-241.

44. A. Bauer, P. Cybulskis and J. L. Green, "Mixed-Nitride Fuel Performance in EBR-II," Proceedings of the Symposium on Advanced LMFBR Fuels, Tucson, AZ, October 10-13, 1977, pp. 299-312.

45. Fernandez, J-P. Glatz, D. Haas, R.J.M. Konings, J. Somers, E. Toscano, C.T. Walker, and D. Wegen. Fuels and targets for incineration and transmutation of actinides: the ITU programme.

46. Prunier, F. Boussard, L. Koch, M. Coquerelle. Some specific aspects of homogeneous Am and Np based fuels transmutation through the outcomes of the SUPERFACT experiment in Phénix fast reactor. p. 158. 
47. Guidez, P. Chaucheprat, B. Fontaine, E. Brunon, L. Martin, D. Warin, A. Zaetta, F. Sudreau. Phénix: The irradiation program for transmutation experiments. p. 399.

48. R.J.M. Konings, R. Conrad, G. Dassel, B.J. Pijlgroms, J. Somers, E. Toscano, “The EFTTRA-T4 Experiment on Americium Transmutation, J.Nucl. Mater. 282 (2000) 159-170.

49. T. Sekine, T. Soga, D. Wootan, S. Koyama, T. Aoyama. "Short Term Irradiation Test of Fuel Containing Minor Actinides Using the Experimental Fast Reactor JOYO.” American Nuclear Society - GLOBAL 2007, Boise, Idaho, September 13, 2007.

50. G.L. Hofman, L.C. Walters, "Metallic Fast Reactor Fuels," chapter 2 in Materials Science and Technology: a Comprehensive Treatment, vol. 10a, Nuclear Materials, VCH (1994).

51. C.L. Trybus, J.E. Sanecki, S.P. Henslee, "Casting of Metallic Fuel Containing Minor Actinide Additions," J. Nuc. Mat., 204 (1993) 50-55.

52. R. McKnight, personal communication, Argonne National Laboratory (2001).

53. A. Hilton, D. L. Porter, and Steven L. Hayes, "Post-irradiation Examination of AFCI Metallic Transmutation Fuels at 8 at.\%," presented at the Summer 2006 American Nuclear Conference, Reno, Nevada, June 2006.

54. Ohta, Nuclear Technology, in-press, 2008.

55. Personnal communication, Dominique Warin, CEA, 2006.

56. C. Chabert, F. Biscarrat, L. Boucher, L. Buiron, M. Meyer, M. Montuir, H. Palancher, G. Rodriguez. "Study of minor actinides transmutation in sodium fast reactor depleted uranium radial blanket." American Nuclear Society - ICAAP 08, Anaheim, CA, June 2008.

57. A. Hilton, D. L. Porter, and Steven L. Hayes, "Post-irradiation Examination of AFCI Nitride and Oxide Transmutation Fuels at 8 at.\%," presented at the Summer 2006 American Nuclear Conference, Reno, Nevada, June 2006.

58. V.A. Tsykanov, A.a. Maershin, A.a. Petukhov, O.V. Skiba, P.T. Porodnov, G.I. Gadzhiev, I.S. Golubenko, E.P. Klochlov, A.A. Teikovtsev, and V.K. Shamardin, "Analysis of Performance of Fuel elements of the BOR-60 Reactor with Vibrocompacted Uranium-Plutonium Oxide Fuel," Soviet Atomic Energy, V.66, no. 5, pp. 329-333, 1989. 